Article

\title{
Revision of Threshold Luminance Levels in Tunnels Aiming to Minimize Energy Consumption at No Cost: Methodology and Case Studies ${ }^{+}$
}

\author{
Lambros T. Doulos ${ }^{1,2, *(\mathbb{D} \text {, Ioannis Sioutis }}{ }^{3}{ }^{-0}$, Aris Tsangrassoulis ${ }^{4}$, Laurent Canale ${ }^{5}(\mathbb{C})$ \\ and Kostantinos Faidas ${ }^{3}$ \\ 1 School of Applied Arts, Hellenic Open University, Parodos Aristotelous 18, 26335 Patras, Greece \\ 2 Lighting Laboratory, School of Electrical and Computer Engineering, National Technical University \\ of Athens, Zografou, 15780 Athens, Greece \\ 3 Nea odos S.A., Nea Erythraia, 15780 Athens, Greece; ISioutis@neaodos.gr (I.S.); KFaidas@neaodos.gr (K.F.) \\ 4 Department of Architecture, University of Thessaly, 38221 Volos, Greece; atsagras@arch.uth.gr \\ 5 LAPLACE (Laboratoire Plasma et Conversion d'Energie), Université de Toulouse, CNRS, INPT, UPS, \\ 31077 Toulouse, France; laurent.canale@laplace.univ-tlse.fr \\ * Correspondence: ldoulos@mail.ntua.gr; Tel.: +30-6937-086820 \\ $+\quad$ This paper is an extended version of our paper published in 2019 IEEE International Conference on \\ Environment and Electrical Engineering and 2019 IEEE Industrial and Commercial Power Systems Europe \\ (EEEIC/I\&CPS Europe), Genova, Italy, June 11th-14th 2019, pp. 1-6.
}

Received: 28 February 2020; Accepted: 28 March 2020; Published: 3 April 2020

\begin{abstract}
Because of the absence of lighting calculation tools at the initial stage of tunnel design, the lighting systems are usually over-dimensioned, leading to over illumination and increased energy consumption. For this reason, a fine-tuning method for switching lighting stages according to the traffic weighted L20 luminance is proposed at no additional cost. The method was applied in a real -case scenario, where L20 luminance of the access zone at eleven (11) existing tunnels was calculated. The traffic weighted method of CR14380 was used in order to calculate the actual luminance levels for the entrance zone. The new transition zone, which decreases luminance curves, was produced and compared with the existing ones. Thus, a new switching control was proposed and programed for the Supervisory Control and Data Acquisition (SCADA) system of the tunnel. The signals of the corresponding eleven L20 meters for a period of eight days were used and the corresponding annual energy consumptions were calculated using the proposed switching program for each tunnel. The results were compared with a number of scenarios in which the existing lighting system was retrofitted with Lighting Emitting Diodes (LED) luminaires. In these scenarios, the new luminaire arrangement was based not only on the existing luminance demand value for the threshold zone, but also on the newly proposed one with two different control techniques (continuous dimming and 10\% step dimming). The fine-tuning method for switching resulted in energy savings between $11 \%$ and $54 \%$ depending on the tunnel when the scenario of the existing installation at no extra cost was used. Energy savings, when LED luminaires were installed, varied between 57\% (for the scenario with existing luminance demand value for the threshold zone and 10\% step dimming) and $85 \%$ (for the scenario with the new calculated luminance demand and continuous dimming).
\end{abstract}

Keywords: energy savings; lighting; optimal control; performance evaluation; tunnel lighting; sustainable tunneling; threshold zone luminance; tunnel management 


\section{Introduction}

Artificial lighting corresponds to more than $20 \%$ of the world's electricity consumption [1]. In Europe (EU28) there are more than 1.6 million $\mathrm{km}$ of illuminated streets that annually consume approximately $35 \mathrm{TWh}$ ) at a cost of $\$ 4$ billion euro for the public authorities [2]. During the last decade there has been ongoing research activity focused on energy management using various types of renewable energy sources [3-5], on recycling [6], on safety [7-10], and a concentrated effort has been made for making street lighting systems sustainable [11-19] and environmentally friendly [20-22]. In addition, during the last few years, the issue of avoiding light pollution [23-28] has gained importance in technical reports [29] and expert discussions [30].

In tunnels, the use of the lighting system should guarantee a safe pass through it, not only during the night but in daytime as well. The drivers should be able to discern the presence of other vehicles and possible obstacles in the road [31,32]. The effect of the "black" hole at the entrance of the tunnel during the day must be avoided. Thus, higher luminance values are required in order to enhance the visual adaptation of the incoming drivers. The higher luminance values needed at the entrance zone are defined by standards. The required luminance values are dependent on the incident daylight on the surrounding surfaces adjacent to the entrance. As mentioned above, visual adaptation demands increased illuminance not only at the tunnel entrance but also for a considerably long distance inside the tunnel all the way up to the interior zone. Unlike buildings, where daylight minimizes lighting needs [33-35], in tunnels it results in an increased number of installed luminaires as well as in increased power consumption for each luminaire [31,32]. This design approach increases energy consumption during the day, since the threshold luminance (Lth) is directly linked to the access zone luminance, which is represented by L20. The latter is defined as the luminance of the tunnel entrance surrounding areas within a conical field of view of $20^{\circ}$, within stopping distance of design speed. It is evident that the variation of daylight throughout the day affects L20 and, thus, the required luminance values inside the threshold zone. Consequently, the control of the active lighting stages of the tunnel is crucial for minimizing energy consumption during the day.

In an effort to minimize the initial costs, the decision-making process of designing a tunnel takes into consideration only the construction costs. The life cycle cost analysis, which also takes into account the maintenance and lighting operational costs, is ignored. Moretti, Cantisani, and Di Mascio compared the expected costs for pavement construction, maintenance, and road lighting of a highway tunnel in Rome [36]. A lighting system was tested inside a tunnel with a concrete pavement and the energy consumption was $29 \%$ lower than in a tunnel with an asphalt pavement [36]. Furthermore, Moretti, Cantisani, Mascio, and Caro investigated the life cycle costs of two different road tunnel pavements and their corresponding lighting systems [37]. López, Grindlay, and Peña-García [38] suggested a sustainability vector for the initial design of a tunnel. The vector presents the degree of sustainability and highlights the necessity for corrective actions when necessary, combining three parameters (a) energy consumption, (b) landscape integration, and (c) construction cost. An installation of semi-transparent tension structures at the entrance portal can lead to significant energy savings [39]. Another way to reduce the luminance requirements and, thus, the energy consumption is the forestation of the surroundings of the portal of tunnels. Energy consumption can be reduced by up to $50 \%$, as long as the specific species that will be used are permitted by the climatic and hydrological conditions of the zone where the tunnel is [40]. Moreover, García-Trenas, J.C. López, and A. Peña-García [41] analyzed how changes in the vegetation at the area surrounding the tunnel entrance can contribute to energy savings for a lighting installation in an Alpine environment. The required illumination levels can also decrease by using structural measures at the approaching zones or at the tunnel mouth [42]. A pre-tunnel lighting may ensure adequate, progressive, physiological adaptation of the user's eyes when approaching the entrance of the tunnel, and contain the overall costs of the artificial lighting system throughout its service life [43].

As energy consumption has become a crucial factor for tunnel design, a number of control systems based on daylight compensation have been investigated for installation in the tunnel entrances [44-47]. 
Gil-Martín, Peña-García, Jiménez, and Hernández-Montes used a scale model in order to test a system with light-pipes [48]. In a follow-up study, the aforementioned authors used a heliostat to guide sunlight into the light-pipes. The results showed a remarkable improvement in the efficacy of light-pipes, in electrical energy consumption and in the number of luminaries used [49]. A semi-transparent tension structure of a polyester set was used just before the entrance to the tunnel. Hence, the threshold zone was extended towards the outside of the tunnel, in order to minimize lighting demands through the utilization of sunlight [50]. In addition, Peña-García and Gomez-Lorente investigated the installation of solar panels in the areas surrounding tunnel portals [51] while Peña-García and Gil-Martín investigated the use of pergolas for energy savings [52]. Unfortunately, the requirement of road surface uniformity was not fulfilled because the lighting levels were extremely low in the shadowed zones as compared to the sunlit zones [52]. Using a diffuser material in the spaces between the pergola beams improved the homogeneity of sunlight and, thus, energy savings [53]. Salam and Mezher [54] calculated 50\% saving in the lighting electrical load with the use of shading structures in existing tunnels. However, energy savings must not be the only parameter to consider during lighting design. In very long tunnels, people's safety may depend on their reactions to the claustrophobic conditions of tunnels, which could range from stress and anxiety to distraction or fear [55].

Except for the initial design of a tunnel and the methods for reducing energy savings, the renewal, measurements [56,57], and maintenance procedures are also crucial elements for the operation of an existing tunnel. These require, among others, the redetermination of the L20 luminance. This can be realized by taking photographs of the entrance of a tunnel from a fixed point at the center of the motorway exactly from the stopping distance, a method that would require stopping or diverting the traffic completely. Lopez and Pena-Garcia [58] proposed a methodology that uses vehicle-based images and trigonometric considerations and does not affect the traffic. Shuguang [59] presented a tunnel lighting optimal control model taking into account both traffic safety and energy-saving issues. His control model takes the demand on brightness, the total average brightness, and the minimum dimming ratio of the luminaires as parameters. The role of dimming $[60,61]$ and light control $[62-64]$ is significant for the selection of luminaires [65-67]. Pachamanov and Pachamanova [68] presented models for the optimization of the lighting distribution of luminaries for tunnels, which allows the incorporation of the characteristics of the reflective properties of the surface of the road in order to obtain energy-efficient light distributions. Salata et al. [69] optimized energy savings considering the lighting system (High Pressure Sodium lamps (HPS) or Lighting Emitting Diodes (LED)) and the type of asphalt (traditional or special asphalt). Furthermore, Salata et al. [70] investigated whether it is possible to minimize energy demands through the usage of an automatic new control system regulating the luminous fluxes of artificial sources with respect to the variation of daylight, which is characteristic of the outdoor environment.

In general, the reduction of tunnel lighting consumption can be realized through proper optimization of the pavement or by retrofitting the lighting system with cost effective LED luminaires. However, energy savings can also be achieved a) with proper control of a tunnel's lighting system, since this is quite commonly organized in a number of active stages, and b) by reevaluating the corresponding luminance values in the threshold zone (Lth) using the L20 values. The scope of this paper is to propose a control strategy according to the new luminance level requirements based on the traffic weighted L20 method (CR14380, [31]) in existing tunnels. The early results of this method were presented in the 2019 IEEE (Institute of Electrical and Electronics Engineers) International Conference on Environment and Electrical Engineering and the 2019 IEEE Industrial and Commercial Power Systems Europe (EEEIC/I\&CPS Europe), in Genova, Italy, June 11th-14th 2019 [71]. In this paper, the Over Lit Triggering Percentage (OLTP) of various circuits was defined. Eleven tunnels were examined and considerable amounts of energy savings and $\mathrm{CO}_{2}$ emission reductions were achieved. 


\section{Materials and Methods}

Most of the tunnels were constructed before the establishment of the European standards and prior to the advent of LEDs. Comparing the luminance requirements of the existing tunnels with the new weighted L20 method, over illumination is evident. Nowadays, that LED technology is mature, retrofitting the existing lighting system has become of particular importance. This paper presents a method that can take place before the renovation of the tunnels. This method results in significant energy savings and lower $\mathrm{CO}_{2}$ emissions at no additional cost. In short, the actions involved are the following: (a) a new calculation method of the stopping distance, (b) the estimation of the corresponding L20 value, and (c) the programming of the Supervisory Control and Data Acquisition (SCADA) system of the tunnel. The proposed method is presented more analytically in Figure 1. The traffic weighted L20 method was used. The main influencing factors for the examined cases were medium for traffic flow (500-1500 vehicles per hour per lane for one-way traffic), and motorized traffic only. According to these two factors, the tunnel class was defined and then, as a next step, the new corresponding threshold zone luminance (Lth') was calculated. The new Lth' value, was used for each tunnel, in order to define the new triggering points of the lighting stages using the SCADA control system. Because of the new lower Lth' values in comparison to the initial Lth values, the triggering points correspond to lower lighting levels and thus to lower amounts of associated energy consumption.

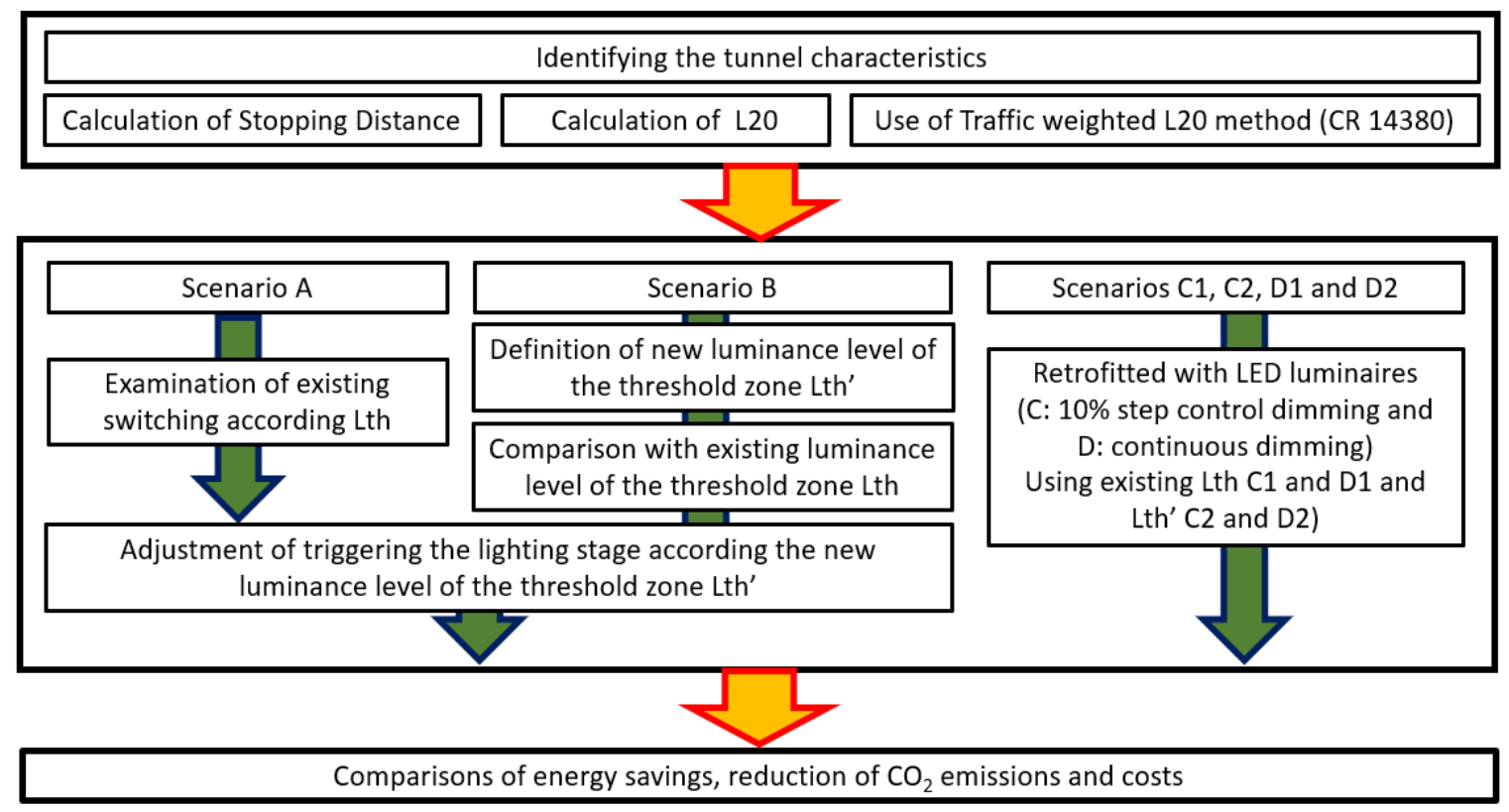

Figure 1. Diagram of the proposed methodology with the examined scenarios. Lighting Emitting Diodes (LED); threshold luminance (Lth); new corresponding threshold zone luminance (Lth').

The following scenarios were examined:

- Scenario A: Switching control with existing Lth values.

- Scenario B: Switching control with newly calculated Lth' values.

- Scenario C1: LED Retrofit 10\% step control dimming (Lth).

- Scenario C2: LED Retrofit 10\% step control dimming (Lth').

- Scenario D1: LED Retrofit continuous dimming (Lth).

- Scenario D2: LED Retrofit continuous dimming (Lth'). 


\subsection{Existing Lighting Infrastructure}

The examined case studies are part of the national motorway Patra-ATHens-Efzoni, (PATHE) in Greece. This national motorway PATHE is one of the 2 motorways connecting Athens to the rest of Greece with an approximate length of $172.5 \mathrm{~km}$. The motorway starts at Metamorfossi (an area in the Prefecture of Attika) and ends at Skarfia, (Prefecture of Fthiotida), after Kamena Vourla. It is a modern motorway using international standards. This PATHE section crosses two regions and three counties and its technical features include among others, 8 bridges, 30 interchanges, 11 tunnels (Figure 2), 1 short tunnel, and 84 underpasses and overpasses.

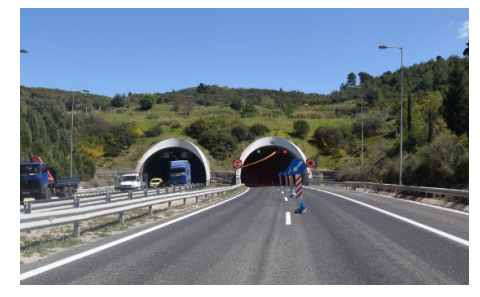

$1 \mathrm{a}$

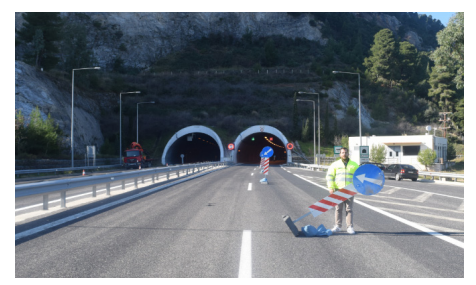

$2 b$

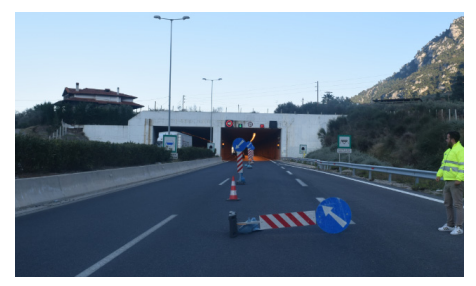

$4 \mathrm{a}$

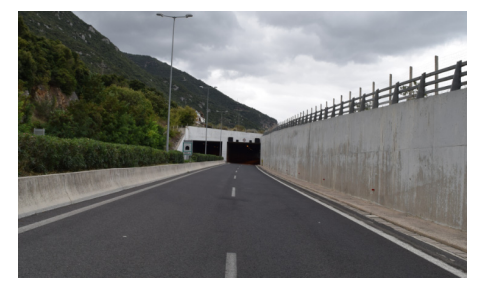

$5 \mathrm{~b}$

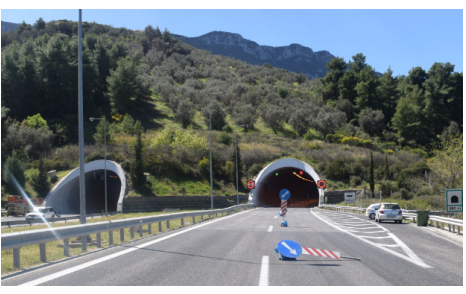

$1 b$

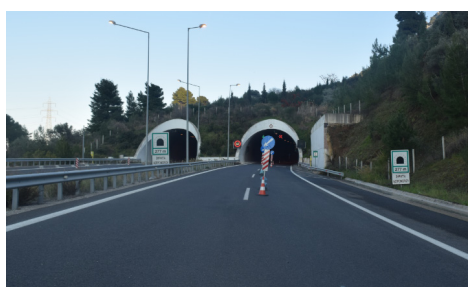

$3 a$

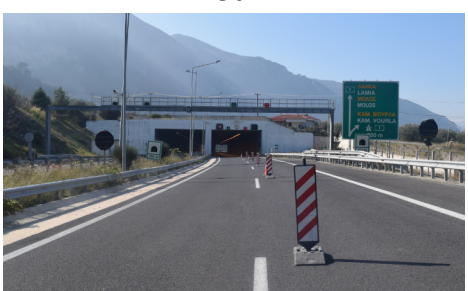

$4 b$

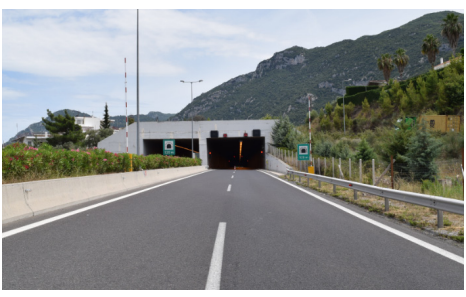

$6 a$

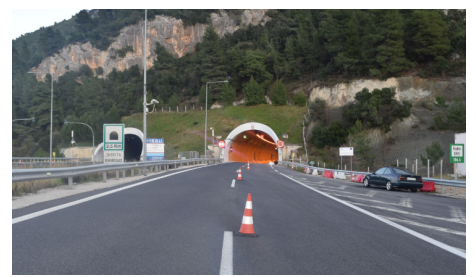

$2 a$

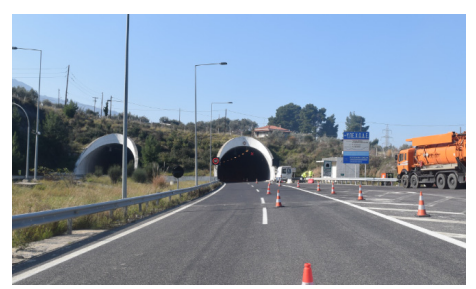

$3 \mathrm{~b}$

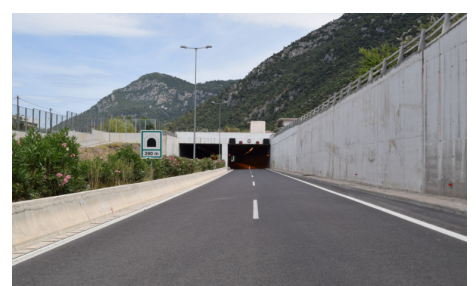

$5 a$

Figure 2. The 11 examined tunnels along the national motorway Patra-ATHens-Efzoni (PATHE) in Greece.

Most of the lighting fixtures for the main road are installed at the intersections. The lighting installation of the road includes 6565 luminaires (main road, intersections, toll areas, parking sites) while the lighting fixtures for the tunnels, without taking into account the underpasses, are 5344 along $8.5 \mathrm{~km}$. The basic characteristics of the eleven tunnels, which were examined together with their lighting system installed power including the power losses from the electromagnetic ballasts, are presented in Tables 1-3. The road has 2 lanes with a total lane width of $7.5 \mathrm{~m}$ and a speed limit of $80 \mathrm{~km} / \mathrm{h}$ in the tunnels. 
Table 1. The basic characteristics of the examined tunnels.

\begin{tabular}{ccccc}
\hline Tunnel & Length $(\mathbf{m})$ & $\begin{array}{c}\text { Length of } \\
\text { Entrance Zone }(\mathbf{m})\end{array}$ & $\begin{array}{c}\text { Length of Interior } \\
\text { Zone } \mathbf{( m )}\end{array}$ & $\begin{array}{c}\text { Threshold Luminance } \\
\left.\text { Lth } \mathbf{( c d} / \mathbf{m}^{\mathbf{2}}\right)\end{array}$ \\
\hline $1 \mathrm{a}$ & 702.1 & 310.7 & 391.4 & 222 \\
$1 \mathrm{~b}$ & 656.4 & 308.1 & 348.3 & 175 \\
$2 \mathrm{a}$ & 2474.7 & 312.0 & 2162.7 & 280 \\
$\mathrm{2b}$ & 2457.6 & 312.0 & 2145.6 & 280 \\
$3 \mathrm{a}$ & 253.4 & 252.0 & 1.4 & 294 \\
$3 \mathrm{~b}$ & 253.4 & 250.7 & 2.7 & 340 \\
$4 \mathrm{a}$ & 294.0 & 280.9 & 13.1 & 194 \\
$4 \mathrm{~b}$ & 286.7 & 286.7 & 0.0 & 216 \\
$5 \mathrm{a}$ & 272.4 & 272.4 & 0.0 & 303 \\
$5 \mathrm{~b}$ & 273.0 & 268.5 & 4.5 & 215 \\
\hline $\mathrm{a}$ & 510.3 & 318.3 & 192.0 & \\
\hline
\end{tabular}

Table 2. Installed power and the corresponding energy indicators for the entrance zone of the examined tunnels.

\begin{tabular}{|c|c|c|c|c|c|c|}
\hline Tunnel & $\begin{array}{c}\text { Installed } \\
\text { Power (kW) }\end{array}$ & $\begin{array}{c}\text { Power } \\
\text { density }\left(\mathrm{W} / \mathrm{m}^{2}\right)\end{array}$ & kW/km & $\begin{array}{c}\text { Number } \\
\text { of Luminaires }\end{array}$ & Luminaire/m & Length (m) \\
\hline $1 \mathrm{a}$ & 123.8 & 53.1 & 398.4 & 305 & 0.98 & 310.7 \\
\hline $1 \mathrm{~b}$ & 125.0 & 54.1 & 405.6 & 305 & 0.99 & 308.1 \\
\hline $2 a$ & 126.3 & 54.0 & 404.8 & 306 & 0.98 & 312.0 \\
\hline $2 b$ & 126.5 & 54.1 & 405.6 & 310 & 0.99 & 312.0 \\
\hline $3 a$ & 97.0 & 51.3 & 384.8 & 222 & 0.88 & 252.0 \\
\hline $3 b$ & 96.8 & 51.5 & 386.0 & 221 & 0.88 & 250.7 \\
\hline $4 a$ & 134.1 & 63.7 & 477.4 & 290 & 1.03 & 280.9 \\
\hline $4 \mathrm{~b}$ & 99.6 & 46.3 & 347.4 & 235 & 0.82 & 286.7 \\
\hline $5 a$ & 110.2 & 54.0 & 404.6 & 262 & 0.96 & 272.4 \\
\hline $5 b$ & 123.2 & 61.2 & 458.8 & 334 & 1.24 & 268.5 \\
\hline $6 a$ & 127.9 & 53.6 & 401.7 & 312 & 0.98 & 318.3 \\
\hline
\end{tabular}

Table 3. Installed power and the corresponding energy indicators for the interior zone and nighttime stage of the examined tunnels (the luminaires of the interior zone were installed along the full length of the tunnel).

\begin{tabular}{|c|c|c|c|c|c|c|}
\hline Tunnel & $\begin{array}{c}\text { Installed } \\
\text { Power (kW) }\end{array}$ & $\begin{array}{l}\text { Power Density } \\
\left(\mathrm{W} / \mathrm{m}^{2}\right)\end{array}$ & $\mathbf{k W / k m}$ & $\begin{array}{l}\text { Number } \\
\text { of Luminaires }\end{array}$ & Luminaire/m & Length (m) \\
\hline $1 \mathrm{a}$ & 30.2 & 5.7 & 43.1 & 160 & 0.23 & 702.1 \\
\hline $1 b$ & 24.2 & 4.9 & 36.8 & 133 & 0.20 & 656.4 \\
\hline $2 \mathrm{a}$ & 144.5 & 7.8 & 58.4 & 744 & 0.30 & 2474.7 \\
\hline $2 b$ & 129.4 & 7.0 & 52.6 & 630 & 0.26 & 2457.6 \\
\hline $3 a$ & 12.2 & 6.4 & 48.3 & 54 & 0.21 & 253.4 \\
\hline $3 b$ & 12.2 & 6.4 & 48.3 & 54 & 0.21 & 253.4 \\
\hline $4 a$ & 20.1 & 9.1 & 68.4 & 82 & 0.28 & 294.0 \\
\hline $4 \mathrm{~b}$ & 15.5 & 7.2 & 54.0 & 64 & 0.22 & 286.7 \\
\hline $5 a$ & 3.2 & 1.6 & 11.9 & 26 & 0.10 & 272.4 \\
\hline $5 b$ & 3.1 & 1.5 & 11.2 & 24 & 0.09 & 273.0 \\
\hline $6 a$ & 13.7 & 3.6 & 26.8 & 80 & 0.16 & 510.3 \\
\hline
\end{tabular}

\subsection{Luminance Calculations (L20)}

As the proposed methodology compares the existing threshold luminance Lth, with the new $\mathrm{Lth}^{\prime}$, the luminance L20 at the access zone has to be calculated. The L20 value can be obtained either from estimation [31] or by using a combination of a photo of the tunnel entrance and corresponding calculations according to the standards [31]. More specifically, the photograph should be taken from a point at a distance equal to the stopping distance from the tunnel portal in the middle of the specific 
motorway or traffic lane with the road closed off [58]. The evaluation of L20 was obtained using the photographs, one for each of the eleven tunnels, presented in Figure 3 with the aid of the equation (1):

$$
\mathrm{L} 20=\gamma \cdot \mathrm{L}_{\mathrm{C}}+\rho \cdot \mathrm{L}_{\mathrm{R}}+\Sigma\left(\varepsilon \cdot \mathrm{L}_{\mathrm{E}}\right)
$$

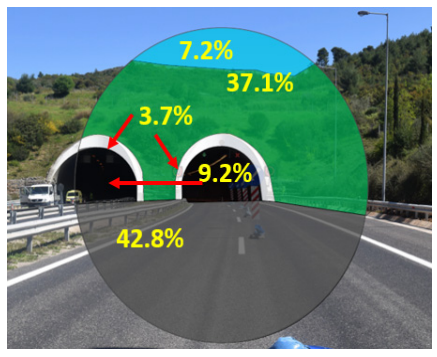

$1 \mathrm{a}$

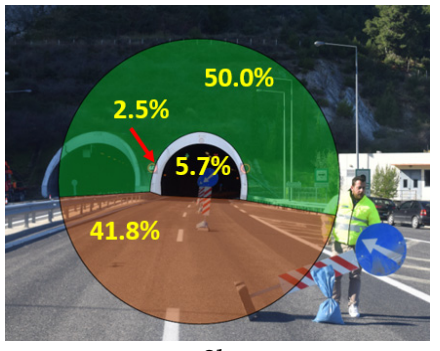

$2 b$

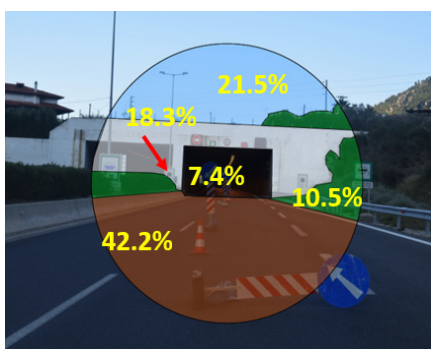

$4 \mathrm{a}$

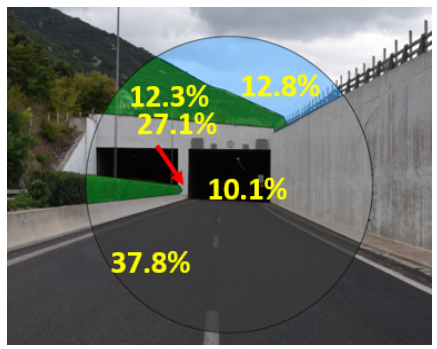

$5 b$

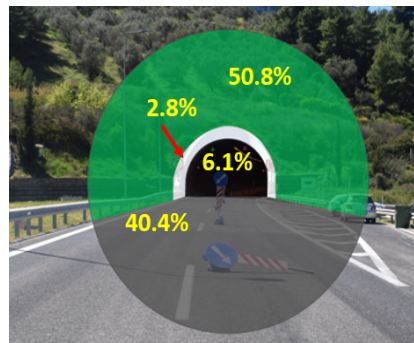

$1 b$

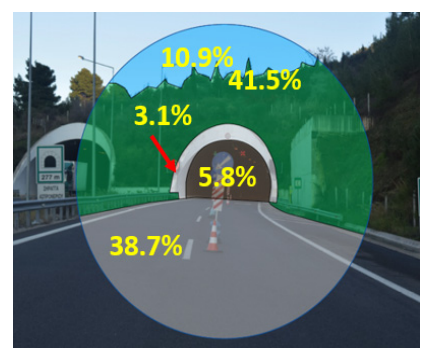

$3 a$

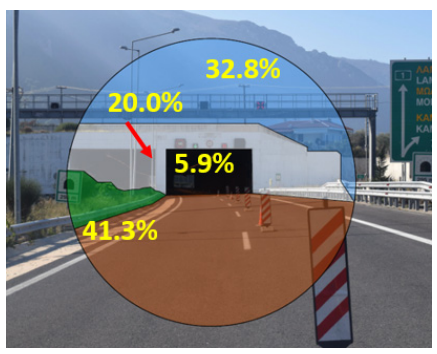

$4 \mathrm{~b}$

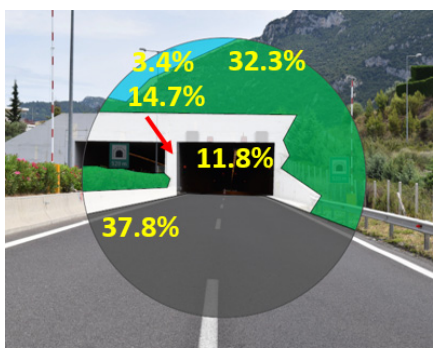

$6 a$

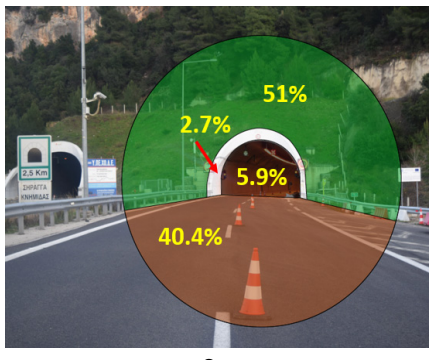

$2 \mathrm{a}$

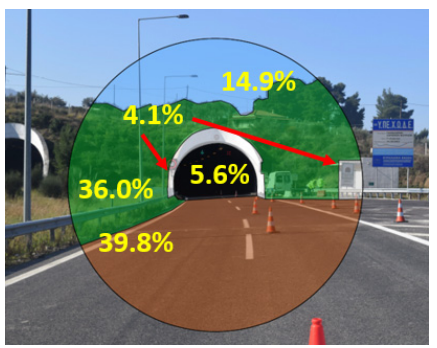

$3 b$

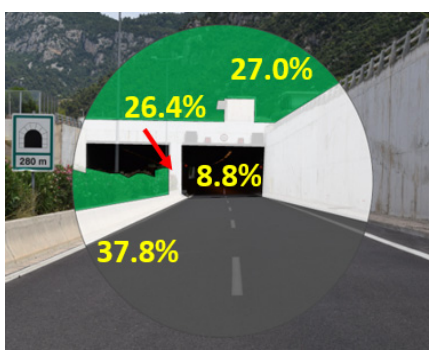

5 a

Figure 3. Photographs, taken from a point at a distance equal to the stopping distance from each of the tunnel portals in the middle of the specific motorway, presenting the parts of sky (\%), road (\%), surroundings (\%), and portal (\%) used for the calculation of the access luminance L20.

Where: $\mathrm{L} 20$ is the access zone luminance, $\mathrm{L}_{\mathrm{C}}$ is the sky luminance, $\gamma=(\%)$ of sky, $\mathrm{L}_{\mathrm{R}}$ is the road luminance, $\rho=(\%)$ of road, $\mathrm{L}_{\mathrm{E}}$ is the surrounding luminance and $\varepsilon=(\%)$ of surroundings.

The parameters used for the calculation of L20 are presented in Table 4 while Table 5 shows the luminance requirement for the new threshold zone Lth'. The $\mathrm{k}$ factor was calculated from Table 6 using interpolation. All the tunnels were classified as class 2 for motorized traffic only and medium 
traffic flow. The new calculated luminance values in each threshold zone are presented in Table 5 . The corresponding Lth' values varied from $26 \%$ to $60 \%$, which was lower than the corresponding existing one Lth, a fact meaning that the lighting systems are over-dimensioned for all the tunnels.

Table 4. Corresponding values used in Equation (1) in order to calculate the L20 [31] luminance for all examined tunnels.

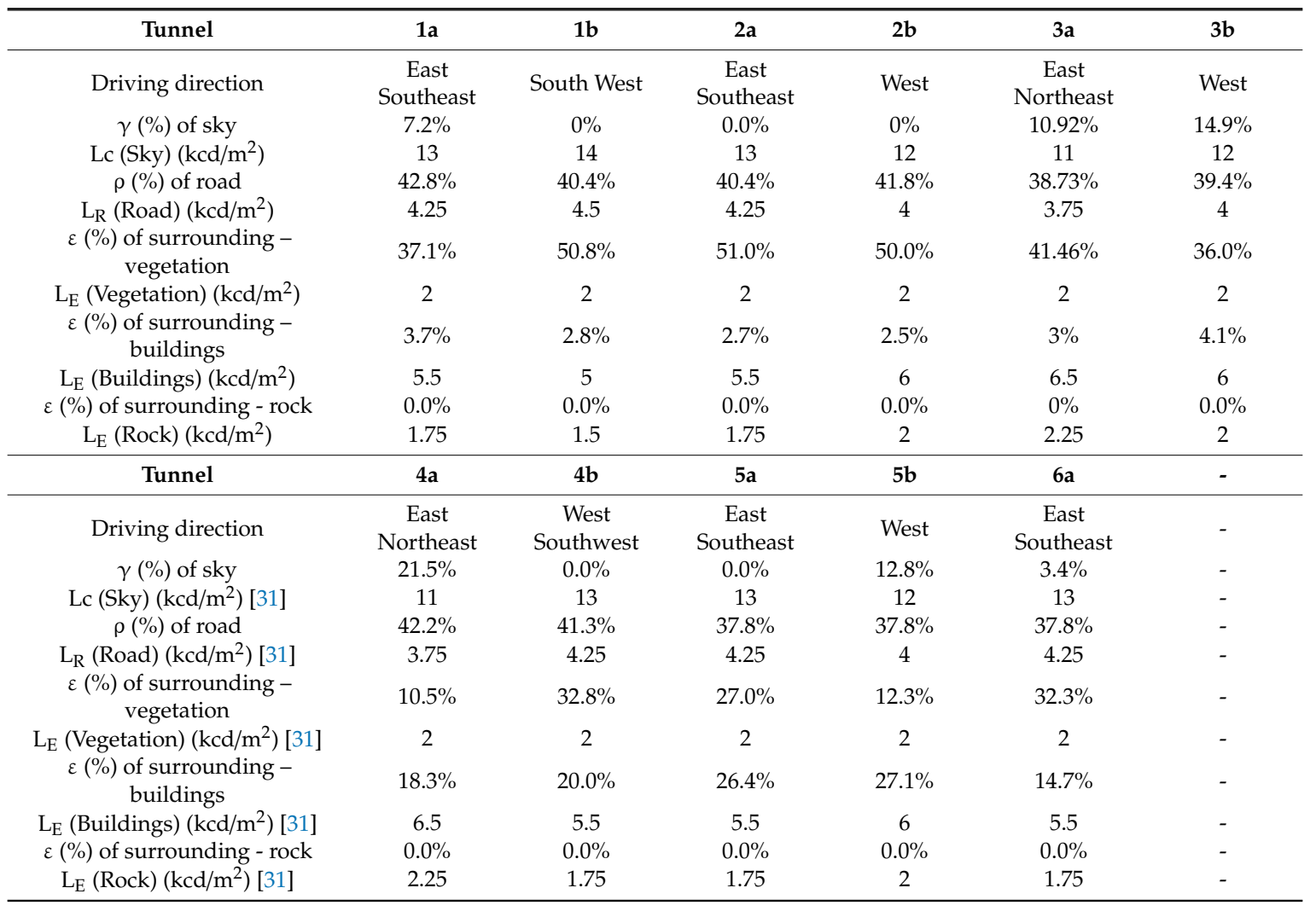

Table 5. Lth' values using the L20 access luminance and corresponding $\mathrm{k}$ factor according the proposed traffic weighted method [31].

\begin{tabular}{|c|c|c|c|}
\hline Tunnel & $\begin{array}{c}\mathrm{L} 20\left(\mathrm{~cd} / \mathrm{m}^{2}\right) \\
\text { (1) }\end{array}$ & $\begin{array}{c}\text { k Factor [31] } \\
\text { (2) }\end{array}$ & $\begin{array}{l}\mathrm{Lth}^{\prime}\left(\mathrm{cd} / \mathrm{m}^{2}\right) \\
(3)=(1) \cdot(2)\end{array}$ \\
\hline $1 \mathrm{a}$ & 3704 & 0.040 & 148 \\
\hline $1 b$ & 2970 & 0.039 & 116 \\
\hline $2 a$ & 2885 & 0.039 & 113 \\
\hline $2 b$ & 2824 & 0.040 & 113 \\
\hline $3 a$ & 3684 & 0.038 & 140 \\
\hline $3 b$ & 4326 & 0.040 & 173 \\
\hline $4 a$ & 5354 & 0.038 & 203 \\
\hline $4 b$ & 3511 & 0.041 & 144 \\
\hline $5 a$ & 3598 & 0.040 & 144 \\
\hline $5 b$ & 4912 & 0.040 & 196 \\
\hline $6 a$ & 3502 & 0.038 & 133 \\
\hline
\end{tabular}

Table 6. Recommended values of $k$ factor for different values of stopping distance (SD) for tunnel class 2 (motorized traffic only and medium traffic flow) using the traffic weighed method [31].

\begin{tabular}{cccc}
\hline \multirow{2}{*}{ Tunnel Class } & \multicolumn{4}{c}{ Stopping Distance SD (m) } \\
& $\mathbf{6 0}$ & $\mathbf{1 0 0}$ & $\mathbf{1 6 0}$ \\
\hline 2 & 0.03 & 0.04 & 0.05 \\
\hline
\end{tabular}




\section{Results}

\subsection{Defining Switching Control}

While the incident daylight at the tunnel portal is not stable during the day, there is a need for a switching control based on the daylight levels. Depending on the control of the lighting stage, the energy consumption for the same tunnel can be considerably modified.

\subsubsection{Existing Switching (Scenario A)}

The existing switching program of the examined tunnel is shown in Table 7. It is based on the signal generated by the L20 luminance meter, which activates the luminaires through the SCADA system. For the existing control switching (Scenario A, Lth) when daylight increases and the L20 value sent to SCADA is larger than the values in Table 7, Stage 1 (S1) is switched on (full light output). If the L20 signal is lower than the corresponding values, then the next lighting stage 2 (S2) is engaged. For example, for Tunnel 1a (Table 7), when L20 value is larger than $1530 \mathrm{~cd} / \mathrm{m}^{2}$, Stage 1 is switched on (full light output, 305 luminaires, $123.8 \mathrm{~kW}$ ). If the $\mathrm{L} 20$ signal is less than $1530 \mathrm{~cd} / \mathrm{m}^{2}$, then the corresponding Stage 2 (S2) is engaged (182 luminaires, $67.3 \mathrm{~kW}$ ).

\subsubsection{Proposed Switching (Scenario B)}

For the proposed switching, the threshold luminance (Lth') is different than the threshold luminance Lth of the initial design. The new CIE (Commission Internationale de l'Eclairage or International Commission on Illumination) curves regarding the new Lth' values are presented in Figure 4 , and it is evident that the existing stage 2 can satisfy the maximum lighting needs in many cases. This results in greater energy savings, since stage 1 will be set permanently to inactive (Tunnels $2 \mathrm{a}$ and $2 \mathrm{~b}$, Table 8 ). In addition, for the next lighting level with the new lower than the existing configuration luminance requirements, S4 is engaged instead of S3. In order to determine the new triggering of the lighting system and the associated L20, a new parameter called Over Lit Triggering Percentage of various circuits (OLTP) is proposed. This percentage is defined as follows:

$$
\mathrm{OLTP}_{\mathrm{SN}}=\mathrm{Lth}(\mathrm{SN}) / \mathrm{Lth}^{\prime}(\mathrm{S} 1)
$$

Where: Lth (SN) is the Lth of the initial design of the existing tunnel for SN light stage, Lth'(S1) is the luminance requirement for the new threshold zone for S1 stage and $\mathrm{SN}$ is the corresponding lighting stage ( $\mathrm{S} 1$ for $\mathrm{N}=1, \mathrm{~S} 2$ for $\mathrm{N}=2$, etc.). Thereafter $\mathrm{OLTP}_{\mathrm{SN}}$ represents (in percentage) the proposed triggering of each of the existing lighting circuit for SN light stage. Values above $100 \%$ meaning that the corresponding switching stage is inactive. This percentage is necessary for the specification of the new triggering of the existed lighting circuits based on the new lower lighting requirements. It is evident that the proposed triggering will now depend on the Lth' and since the existing lighting achieves specific lighting levels due to the existing lighting circuits, their triggering has to be redefined. Hence, the proposed switching control, Scenario B (Table 8) enables all stages at higher values of L20 when compared to the existing configuration. This means that the use of lighting control stages with fewer luminaires and less installed power instead of the existing ones, for the same incident daylight at the portal of the tunnel, can lead to a larger amount of energy savings and lower amounts of $\mathrm{CO}_{2}$ emissions. 
Table 7. Extracted L20 values from Supervisory Control and Data Acquisition (SCADA) system for Scenario A (switching control with existing Lth values) along with the number of luminaires grouped per lighting stage and the corresponding installed power for all the examined tunnels.

\begin{tabular}{|c|c|c|c|c|c|c|c|}
\hline Tunnel & $\begin{array}{l}\text { Lighting } \\
\text { Stage }\end{array}$ & $\begin{array}{l}\text { Light } \\
\text { Output }\end{array}$ & $\begin{array}{l}\text { Switching on/off, } \\
\text { L20 Luminance } \\
\text { Signal } \\
\text { for SCADA }\left(\mathrm{cd} / \mathrm{m}^{2}\right)\end{array}$ & $\begin{array}{c}\text { Power of } \\
\text { Luminaires in } \\
\text { Operation per } \\
\text { Stage }(\mathbf{k W})\end{array}$ & $\begin{array}{l}\text { Power of } \\
\text { Luminaires } \\
\text { per } \\
\text { Stage }(\mathbf{k W})\end{array}$ & $\begin{array}{l}\text { Luminaires } \\
\text { in } \\
\text { Operation } \\
\text { per Stage }\end{array}$ & $\begin{array}{l}\text { Luminaires } \\
\text { per Stage }\end{array}$ \\
\hline \multirow{5}{*}{$1 \mathrm{a}$} & S1 & $100 \%$ & 1530 & 123.8 & 56.5 & 305 & 123 \\
\hline & S2 & $50 \%$ & 630 & 67.3 & 34.0 & 182 & 80 \\
\hline & S3 & $20 \%$ & 225 & 33.4 & 21.5 & 102 & 51 \\
\hline & S4 & $6 \%$ & 90 & 11.8 & 6.8 & 51 & 25 \\
\hline & S5 & $3 \%$ & 27 & 5.0 & 5.0 & 26 & 26 \\
\hline \multirow{5}{*}{$1 \mathrm{~b}$} & S1 & $100 \%$ & 1530 & 125.0 & 57.2 & 305 & 125 \\
\hline & S2 & $50 \%$ & 630 & 67.7 & 33.5 & 180 & 78 \\
\hline & S3 & $20 \%$ & 225 & 34.3 & 21.8 & 102 & 50 \\
\hline & S4 & $6 \%$ & 90 & 12.4 & 7.3 & 52 & 25 \\
\hline & S5 & $3 \%$ & 27 & 5.2 & 5.2 & 27 & 27 \\
\hline \multirow{5}{*}{$2 a$} & S1 & $100 \%$ & 1530 & 126.3 & 60.8 & 306 & 135 \\
\hline & S2 & $50 \%$ & 630 & 65.5 & 34.3 & 171 & 80 \\
\hline & S3 & $20 \%$ & 225 & 31.2 & 23.6 & 91 & 54 \\
\hline & S4 & $6 \%$ & 90 & 7.6 & 2.5 & 37 & 10 \\
\hline & S5 & $3 \%$ & 27 & 5.2 & 5.2 & 27 & 27 \\
\hline \multirow{5}{*}{$2 \mathrm{~b}$} & S1 & $100 \%$ & 1530 & 126.5 & 58.1 & 310 & 127 \\
\hline & S2 & $50 \%$ & 630 & 68.5 & 32.8 & 183 & 77 \\
\hline & S3 & $20 \%$ & 225 & 35.6 & 23.1 & 106 & 53 \\
\hline & S4 & $6 \%$ & 90 & 12.5 & 7.6 & 53 & 27 \\
\hline & S5 & $3 \%$ & 27 & 5.0 & 5.0 & 26 & 26 \\
\hline \multirow{5}{*}{$3 a$} & S1 & $100 \%$ & 1180 & 97.0 & 50.4 & 222 & 107 \\
\hline & S2 & $50 \%$ & 620 & 46.6 & 27.7 & 115 & 59 \\
\hline & S3 & $20 \%$ & 420 & 18.9 & 14.7 & 56 & 32 \\
\hline & S4 & $6 \%$ & 190 & 4.2 & 0.3 & 24 & 2 \\
\hline & S5 & $3 \%$ & 90 & 3.9 & 3.9 & 22 & 22 \\
\hline \multirow{5}{*}{$3 b$} & S1 & $100 \%$ & 1200 & 96.8 & 49.7 & 221 & 105 \\
\hline & S2 & $50 \%$ & 850 & 47.0 & 27.7 & 116 & 59 \\
\hline & S3 & $20 \%$ & 420 & 19.4 & 15.2 & 57 & 33 \\
\hline & S4 & $6 \%$ & 260 & 4.2 & 0.3 & 24 & 2 \\
\hline & S5 & $3 \%$ & 90 & 3.9 & 3.9 & 22 & 22 \\
\hline \multirow{5}{*}{$4 a$} & S1 & $100 \%$ & 2370 & 134.1 & 56.5 & 290 & 118 \\
\hline & S2 & $50 \%$ & 1100 & 77.6 & 47.8 & 172 & 100 \\
\hline & S3 & $20 \%$ & 600 & 29.8 & 21.4 & 72 & 45 \\
\hline & S4 & $6 \%$ & 200 & 8.4 & 5.6 & 27 & 12 \\
\hline & S5 & $3 \%$ & 90 & 2.8 & 2.8 & 15 & 15 \\
\hline \multirow{5}{*}{$4 b$} & S1 & $100 \%$ & 2000 & 99.6 & 49.1 & 235 & 105 \\
\hline & S2 & $50 \%$ & 1000 & 50.5 & 29.5 & 130 & 66 \\
\hline & S3 & $20 \%$ & 650 & 20.9 & 16.0 & 64 & 36 \\
\hline & S4 & $6 \%$ & 410 & 4.9 & 0.7 & 28 & 4 \\
\hline & S5 & $3 \%$ & 270 & 4.3 & 4.3 & 24 & 24 \\
\hline \multirow{5}{*}{$5 a$} & S1 & $100 \%$ & 1800 & 110.2 & 51.6 & 262 & 111 \\
\hline & S2 & $50 \%$ & 850 & 58.6 & 30.4 & 151 & 67 \\
\hline & S3 & $20 \%$ & 510 & 28.2 & 17.6 & 84 & 39 \\
\hline & S4 & $6 \%$ & 360 & 10.6 & 6.7 & 45 & 23 \\
\hline & S5 & $3 \%$ & 290 & 4.0 & 4.0 & 22 & 22 \\
\hline \multirow{5}{*}{$5 b$} & S1 & $100 \%$ & 1480 & 147.8 & 59.3 & 334 & 127 \\
\hline & S2 & $50 \%$ & 720 & 88.5 & 50.8 & 207 & 110 \\
\hline & S3 & $20 \%$ & 480 & 37.7 & 22.9 & 97 & 50 \\
\hline & S4 & $6 \%$ & 230 & 14.8 & 9.2 & 47 & 24 \\
\hline & S5 & $3 \%$ & 140 & 5.6 & 5.6 & 23 & 23 \\
\hline \multirow{5}{*}{$6 a$} & S1 & $100 \%$ & 1580 & 127.9 & 57.1 & 312 & 125 \\
\hline & S2 & $50 \%$ & 830 & 70.7 & 35.2 & 187 & 82 \\
\hline & S3 & $20 \%$ & 370 & 35.5 & 23.1 & 105 & 53 \\
\hline & S4 & $6 \%$ & 280 & 12.4 & 7.3 & 52 & 26 \\
\hline & S5 & $3 \%$ & 100 & 5.2 & 5.2 & 26 & 26 \\
\hline
\end{tabular}



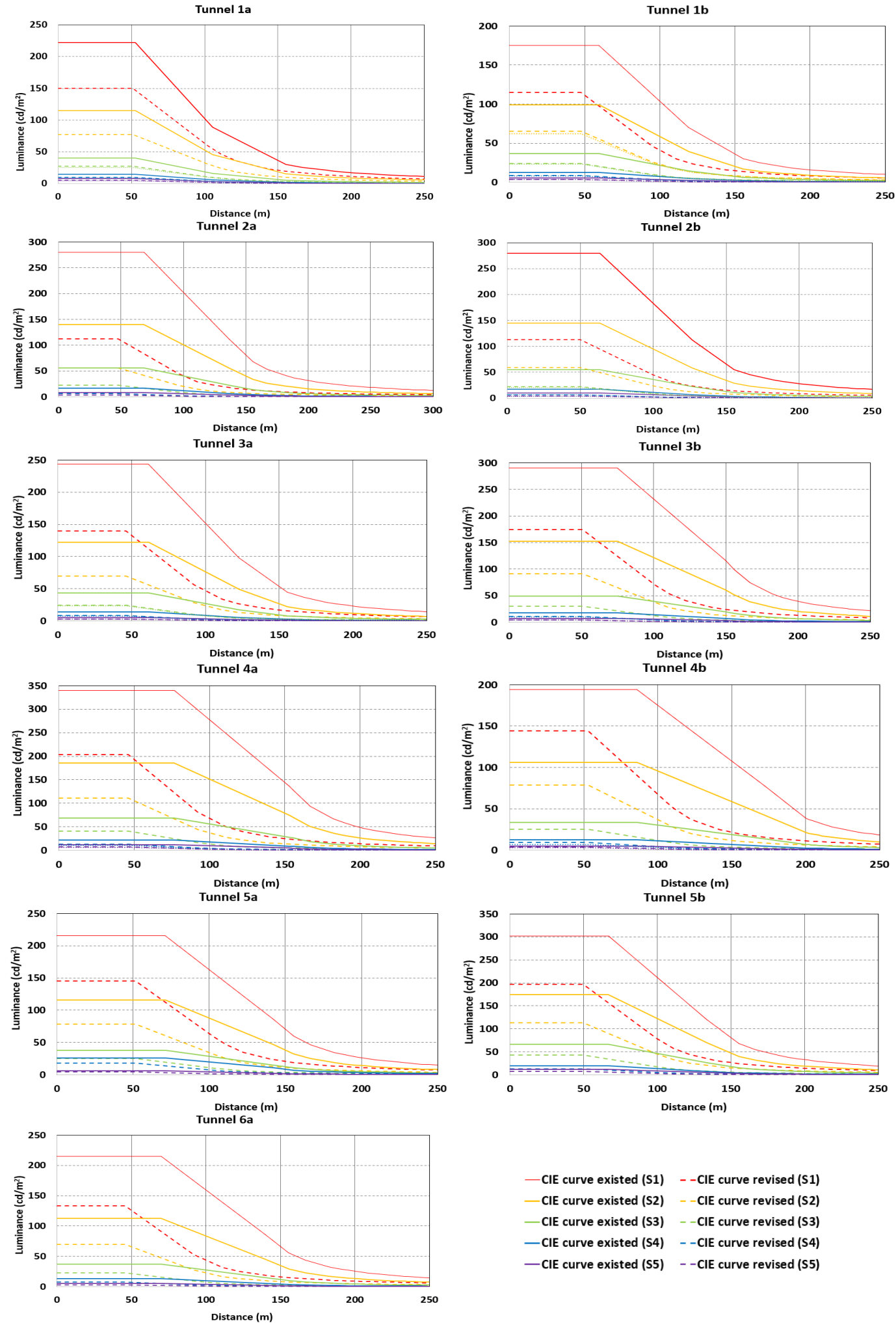

Figure 4. Luminance curves from initial design (existing lighting system) and from the traffic weighted method using the new calculated Lth' values, according to the Commission Internationale de l'Eclairage (CIE) for the examined tunnels. 
Table 8. Comparison of the switching control between Scenario A (switching control with existing Lth values) and Scenario B (switching control with new proposed Lth' values) for all examined tunnels. OLTP $=$ Over Lit Triggering Percentage.

\begin{tabular}{|c|c|c|c|c|c|c|c|c|}
\hline Tun. & Stage & Lth $\left(\mathrm{cd} / \mathrm{m}^{2}\right)$ & $\begin{array}{c}\text { Lth' from } \\
\text { Revised CIE } \\
\text { Curve }\left(\mathrm{cd} / \mathrm{m}^{2}\right)\end{array}$ & $\begin{array}{c}\text { OLTP due to } \\
\text { New } \\
\text { Luminance } \\
\text { Demand, (\%) }\end{array}$ & $\begin{array}{l}\text { Light Output } \\
\text { Levels for } \\
\text { Existing } \\
\text { Switching }\end{array}$ & $\begin{array}{l}\text { L20 Triggering } \\
\text { Levels for } \\
\text { SCADA }\left(\mathrm{cd} / \mathrm{m}^{2}\right)\end{array}$ & $\begin{array}{l}\text { Light Output } \\
\text { Levels for } \\
\text { Proposed } \\
\text { Switching }\end{array}$ & $\begin{array}{c}\text { New L20 } \\
\text { Triggering } \\
\text { Levels for } \\
\text { SCADA }\left(\mathrm{cd} / \mathrm{m}^{2}\right)\end{array}$ \\
\hline \multirow{5}{*}{$1 \mathrm{a}$} & S1 & 222 & 148 & $150 \%$ & $50 \%$ & 1530 & $75 \%$ & 2780 \\
\hline & S2 & 111 & 74 & $75 \%$ & $20 \%$ & 630 & $30 \%$ & 1112 \\
\hline & S3 & 44 & 30 & $30 \%$ & $6 \%$ & 225 & $9 \%$ & 334 \\
\hline & S4 & 13 & 9 & $9 \%$ & $3 \%$ & 90 & $5 \%$ & 167 \\
\hline & S5 & 7 & 4 & $5 \%$ & $0 \%$ & 27 & $0 \%$ & 0 \\
\hline \multirow{5}{*}{$1 \mathrm{~b}$} & S1 & 175 & 116 & $151 \%$ & $50 \%$ & 1530 & $75 \%$ & 2238 \\
\hline & S2 & 87 & 58 & $75 \%$ & $20 \%$ & 630 & $30 \%$ & 895 \\
\hline & S3 & 35 & 23 & $30 \%$ & $6 \%$ & 225 & $9 \%$ & 269 \\
\hline & S4 & 10 & 7 & $9 \%$ & $3 \%$ & 90 & $5 \%$ & 134 \\
\hline & S5 & 5 & 3 & $5 \%$ & $0 \%$ & 27 & $0 \%$ & 0 \\
\hline \multirow{5}{*}{$2 a$} & S1 & 280 & 113 & $249 \%$ & $50 \%$ & 1530 & No use & No use \\
\hline & S2 & 140 & 56 & $124 \%$ & $20 \%$ & 630 & $50 \%$ & 1436 \\
\hline & S3 & 56 & 23 & $50 \%$ & $6 \%$ & 225 & $15 \%$ & 431 \\
\hline & S4 & 17 & 7 & $15 \%$ & $3 \%$ & 90 & $7 \%$ & 215 \\
\hline & S5 & 8 & 3 & $7 \%$ & $0 \%$ & 27 & $0 \%$ & 0 \\
\hline \multirow{5}{*}{$2 b$} & S1 & 280 & 113 & $248 \%$ & $50 \%$ & 1530 & No use & No use \\
\hline & S2 & 140 & 57 & $124 \%$ & $20 \%$ & 630 & $50 \%$ & 1400 \\
\hline & S3 & 56 & 23 & $50 \%$ & $6 \%$ & 225 & $15 \%$ & 420 \\
\hline & S4 & 17 & 7 & $15 \%$ & $3 \%$ & 90 & $7 \%$ & 210 \\
\hline & S5 & 8 & 3 & $7 \%$ & $0 \%$ & 27 & $0 \%$ & 0 \\
\hline \multirow{5}{*}{$3 a$} & S1 & 244 & 140 & $174 \%$ & $50 \%$ & 1180 & $87 \%$ & 3209 \\
\hline & S2 & 122 & 70 & $87 \%$ & $20 \%$ & 620 & $35 \%$ & 1416 \\
\hline & S3 & 49 & 25 & $35 \%$ & $6 \%$ & 420 & $10 \%$ & 425 \\
\hline & S4 & 15 & 8 & $10 \%$ & $3 \%$ & 190 & $5 \%$ & 212 \\
\hline & S5 & 7 & 4 & $5 \%$ & $0 \%$ & 90 & $0 \%$ & 0 \\
\hline \multirow{5}{*}{$3 b$} & S1 & 290 & 173 & $168 \%$ & $50 \%$ & 1200 & $84 \%$ & 3626 \\
\hline & S2 & 145 & 82 & $88 \%$ & $20 \%$ & 850 & $34 \%$ & 1451 \\
\hline & S3 & 58 & 33 & $29 \%$ & $6 \%$ & 420 & $10 \%$ & 435 \\
\hline & S4 & 17 & 10 & $11 \%$ & $3 \%$ & 260 & $5 \%$ & 218 \\
\hline & S5 & 9 & 5 & $4 \%$ & $0 \%$ & 90 & $0 \%$ & 0 \\
\hline \multirow{5}{*}{$4 a$} & S1 & 340 & 203 & $167 \%$ & $50 \%$ & 2370 & $84 \%$ & 4476 \\
\hline & S2 & 170 & 102 & $84 \%$ & $20 \%$ & 1100 & $33 \%$ & 1791 \\
\hline & S3 & 68 & 41 & $33 \%$ & $6 \%$ & 600 & $10 \%$ & 537 \\
\hline & S4 & 20 & 12 & $10 \%$ & $3 \%$ & 200 & $5 \%$ & 269 \\
\hline & S5 & 10 & 6 & $5 \%$ & $0 \%$ & 90 & $0 \%$ & 0 \\
\hline \multirow{5}{*}{$4 \mathrm{~b}$} & S1 & 194 & 144 & $135 \%$ & $50 \%$ & 2000 & $67 \%$ & 2366 \\
\hline & S2 & 97 & 72 & $67 \%$ & $20 \%$ & 1000 & $27 \%$ & 947 \\
\hline & S3 & 39 & 29 & $27 \%$ & $6 \%$ & 650 & $8 \%$ & 284 \\
\hline & S4 & 12 & 9 & $8 \%$ & $3 \%$ & 410 & $4 \%$ & 142 \\
\hline & S5 & 6 & 4 & $4 \%$ & $0 \%$ & 270 & $0 \%$ & 0 \\
\hline \multirow{5}{*}{$5 a$} & S1 & 216 & 144 & $150 \%$ & $50 \%$ & 1800 & $75 \%$ & 2695 \\
\hline & S2 & 108 & 72 & $75 \%$ & $20 \%$ & 850 & $30 \%$ & 1078 \\
\hline & S3 & 43 & 29 & $30 \%$ & $6 \%$ & 510 & $9 \%$ & 323 \\
\hline & S4 & 13 & 9 & $9 \%$ & $3 \%$ & 360 & $4 \%$ & 151 \\
\hline & S5 & 6 & 4 & $4 \%$ & $0 \%$ & 290 & $0 \%$ & 0 \\
\hline \multirow{5}{*}{$5 b$} & S1 & 303 & 197 & $154 \%$ & $50 \%$ & 1480 & $77 \%$ & 3787 \\
\hline & S2 & 152 & 98 & $77 \%$ & $20 \%$ & 720 & $31 \%$ & 1515 \\
\hline & S3 & 61 & 39 & $31 \%$ & $6 \%$ & 480 & $9 \%$ & 454 \\
\hline & S4 & 18 & 12 & $9 \%$ & $3 \%$ & 230 & $6 \%$ & 296 \\
\hline & S5 & 12 & 8 & $6 \%$ & $0 \%$ & 140 & $0 \%$ & 0 \\
\hline \multirow{5}{*}{$6 a$} & S1 & 215 & 133 & $161 \%$ & $50 \%$ & 1580 & $81 \%$ & 2826 \\
\hline & S2 & 107 & 57 & $81 \%$ & $20 \%$ & 830 & $32 \%$ & 1131 \\
\hline & S3 & 43 & 23 & $32 \%$ & $6 \%$ & 370 & $10 \%$ & 339 \\
\hline & S4 & 13 & 7 & $10 \%$ & $3 \%$ & 280 & $5 \%$ & 170 \\
\hline & S5 & 6 & 3 & $5 \%$ & $0 \%$ & 100 & $0 \%$ & 0 \\
\hline
\end{tabular}

\subsection{Use of LED Luminaires (Scenarios C1, D1, C2, and D2)}

In addition, four scenarios were examined where the existing lighting system for each tunnel was retrofitted with LED luminaires (C: 10\% step control dimming and D: continuous dimming) using both the existing lighting requirements Lth and the new calculated Lth' (C1 and D1 for Lth and C2 and D2 for Lth'). Tables 9 and 10 present the number of LED luminaires needed and the corresponding installed power for all scenarios. The data were extracted with the use of the Relux Tunnel light simulation tool [72]. Furthermore, the power density indicator for the entrance zone of the tunnel was calculated as the ratio of its installed power to the area that is defined by the length of the entrance zone of each tunnel and the width of both lanes of the road $(7.5 \mathrm{~m})$. 
Table 9. Number of LED luminaires needed and the corresponding installed power and the energy indicators for the entrance zone of the examined tunnels for existing Lth luminance requirement.

\begin{tabular}{ccccccc}
\hline Tunnel & $\begin{array}{c}\text { Installed } \\
\text { Power }(\mathbf{k W})\end{array}$ & $\begin{array}{c}\text { Power Density } \\
\mathbf{( W / \mathbf { m } ^ { 2 } )}\end{array}$ & $\mathbf{k W / k m}$ & $\begin{array}{c}\text { Number } \\
\text { of Luminaires }\end{array}$ & Luminaire/m & Length (m) \\
\hline 1a & 78.8 & 33.8 & 253.6 & 207 & 0.67 & 310.7 \\
1b & 60.5 & 26.2 & 196.5 & 165 & 0.54 & 308.1 \\
2a & 64.3 & 27.5 & 206.1 & 175 & 0.56 & 312.0 \\
2b & 61.8 & 26.4 & 198.0 & 168 & 0.54 & 312.0 \\
3a & 72.3 & 38.2 & 286.8 & 186 & 0.74 & 252.0 \\
3b & 78.3 & 41.6 & 312.3 & 196 & 0.78 & 250.7 \\
4a & 72.2 & 34.3 & 257.0 & 190 & 0.68 & 280.9 \\
4b & 68.4 & 31.8 & 238.5 & 179 & 0.62 & 286.7 \\
5a & 66.3 & 32.4 & 243.2 & 171 & 0.63 & 272.4 \\
5b & 77.1 & 38.3 & 287.0 & 195 & 0.73 & 268.5 \\
6a & 66.4 & 27.8 & 208.7 & 186 & 0.58 & 318.3 \\
\hline
\end{tabular}

Table 10. Number of LED luminaires needed and the corresponding installed power and the energy indicators for the entrance zone of the examined tunnels for the new calculated Lth' luminance requirement.

\begin{tabular}{|c|c|c|c|c|c|c|}
\hline Tunnel & $\begin{array}{c}\text { Installed } \\
\text { Power (kW) }\end{array}$ & $\begin{array}{l}\text { Power Density } \\
\left(\mathrm{W} / \mathrm{m}^{2}\right)\end{array}$ & kW/km & $\begin{array}{c}\text { Number } \\
\text { of Luminaires }\end{array}$ & Luminaire/m & Length (m) \\
\hline $1 \mathrm{a}$ & 31.3 & 13.4 & 100.9 & 124 & 0.40 & 310.7 \\
\hline $1 \mathrm{~b}$ & 22.9 & 9.9 & 74.3 & 94 & 0.31 & 308.1 \\
\hline $2 a$ & 22.5 & 9.6 & 72.0 & 91 & 0.29 & 312.0 \\
\hline $2 b$ & 23.2 & 9.9 & 74.4 & 96 & 0.31 & 312.0 \\
\hline $3 a$ & 26.9 & 14.2 & 106.8 & 104 & 0.41 & 252.0 \\
\hline $3 b$ & 36.9 & 19.6 & 147.1 & 136 & 0.54 & 250.7 \\
\hline $4 a$ & 34.8 & 16.5 & 124.0 & 133 & 0.47 & 280.9 \\
\hline $4 \mathrm{~b}$ & 28.2 & 13.1 & 98.5 & 110 & 0.38 & 286.7 \\
\hline $5 a$ & 26.7 & 13.1 & 98.0 & 104 & 0.38 & 272.4 \\
\hline $5 b$ & 36.6 & 18.2 & 136.3 & 137 & 0.51 & 268.5 \\
\hline $6 a$ & 23.7 & 9.9 & 74.5 & 98 & 0.31 & 318.3 \\
\hline
\end{tabular}

\subsection{Energy Calculations}

For the corresponding energy calculations, eight days, from 5 February, 2020 to 13 February, 2020, were considered. The readings of the input signal of the lighting system and the switching control were taken from SCADA, as luminance values per minute. Six scenarios were used:

- Scenario A: Switching control with existing Lth values.

- Scenario B: Switching control with newly calculated Lth' values.

- Scenario C1: LED Retrofit 10\% step control dimming (Lth).

- Scenario C2: LED Retrofit 10\% step control dimming (Lth').

- Scenario D1: LED Retrofit continuous dimming (Lth).

- Scenario D2: LED Retrofit continuous dimming (Lth').

The L20 signals, for each of the eleven tunnels, are presented in Figures 5 and 6. Table 11 presents the analytic energy calculations for Scenarios A and B. For each scenario the cumulative energy consumption was separately calculated for each lighting stage. It is evident that by minimizing the working hours of lighting stage S1 (maximum light output) the energy saving is maximized. Table 12 presents the total energy consumption for each of the six examined scenarios and their corresponding energy savings. 


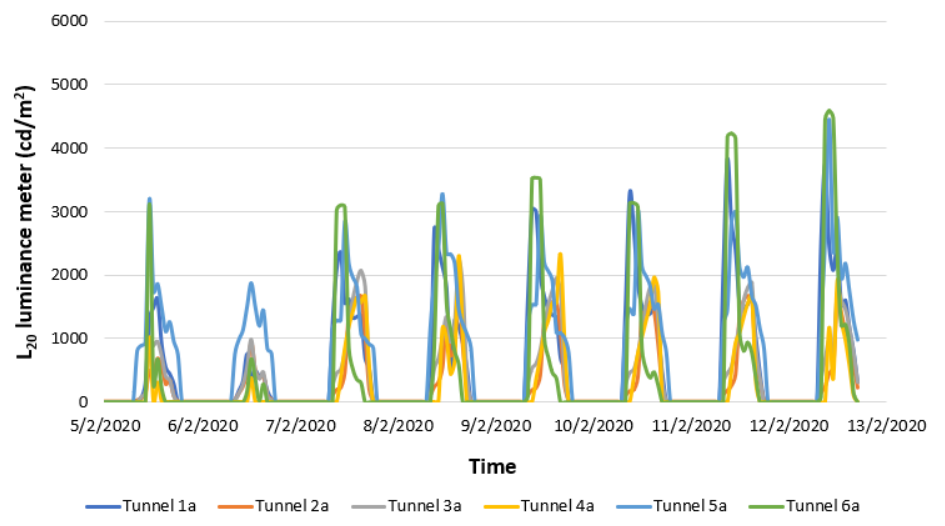

Figure 5. Signal from SCADA due to daylight variation (eight days) for the examined tunnels in the lanes leading to Athens (Tunnels 1a, 2a, 3a, 4a, 5a, and 6a).

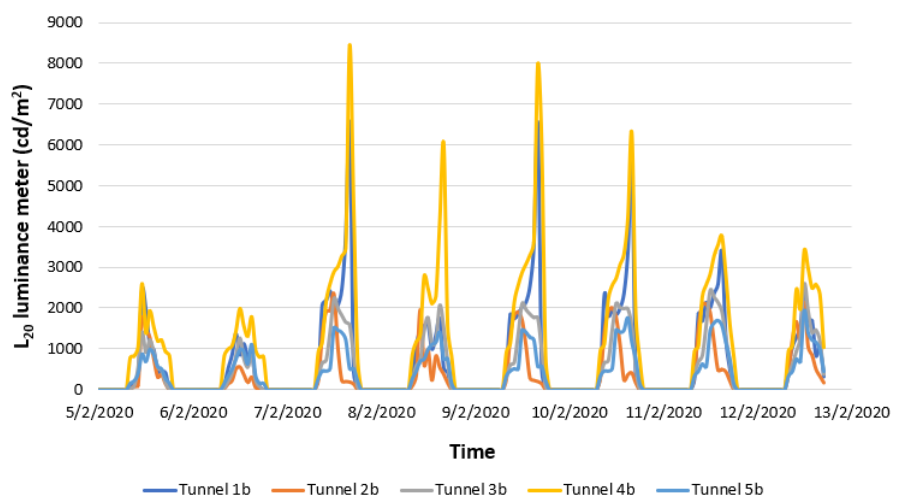

Figure 6. Signal from SCADA due to daylight variation (eight days) for the examined tunnels in the lanes leading to Lamia (Tunnels $1 b, 2 b, 3 b, 4 b$, and 5b).

Table 11. Comparison of the energy consumption $(\mathrm{kWh})$ between the switching scenarios A and B for the period from 5 February, 2020 to 13 February, 2020.

\begin{tabular}{ccccccccc}
\hline \multirow{2}{*}{$\begin{array}{c}\text { Lighting } \\
\text { Stage }\end{array}$} & \multicolumn{7}{c}{ Energy Consumption (kWh) } \\
\cline { 2 - 10 } & $\begin{array}{c}\text { Existing } \\
\text { Switching }\end{array}$ & $\begin{array}{c}\text { Proposed } \\
\text { Switching }\end{array}$ & $\begin{array}{c}\text { Existing } \\
\text { Switching }\end{array}$ & $\begin{array}{c}\text { Proposed } \\
\text { Switching }\end{array}$ & $\begin{array}{c}\text { Existing } \\
\text { Switching }\end{array}$ & $\begin{array}{c}\text { Proposed } \\
\text { Switching }\end{array}$ & $\begin{array}{c}\text { Existing } \\
\text { Switching }\end{array}$ & $\begin{array}{c}\text { Proposed } \\
\text { Switching }\end{array}$ \\
\hline Tunnel & $\mathbf{1 a}$ & $\mathbf{1 a}$ & $\mathbf{1 b}$ & $\mathbf{1 b}$ & $\mathbf{2 a}$ & $\mathbf{2 a}$ & $\mathbf{2 b}$ & $\mathbf{2 b}$ \\
\hline S1 & 4333 & 743 & 6000 & 2500 & 1389 & 0 & 2404 & 0 \\
S2 & 222 & 3432 & 1286 & 2843 & 1769 & 786 & 1370 & 1507 \\
S3 & 568 & 835 & 720 & 823 & 842 & 1123 & 1104 & 926 \\
S4 & 35 & 71 & 25 & 37 & 160 & 137 & 225 & 300 \\
S5 & 30 & 25 & 21 & 26 & 21 & 125 & 15 & 95 \\
Total & 7187 & 5106 & 8052 & 6230 & 4181 & 2171 & 5117 & 2828 \\
\hline Tunnel & $\mathbf{3 a}$ & $\mathbf{3 a}$ & $\mathbf{3 b}$ & $3 \mathbf{b}$ & $\mathbf{4 a}$ & $\mathbf{4 a}$ & $\mathbf{4 b}$ & $\mathbf{4 b}$ \\
\hline S1 & 2910 & 0 & 4259 & 0 & 0 & 0 & 5080 & 4183 \\
S2 & 1025 & 1072 & 423 & 1457 & 1940 & 310 & 1364 & 1313 \\
S3 & 246 & 794 & 446 & 873 & 447 & 1162 & 481 & 690 \\
S4 & 76 & 76 & 29 & 42 & 109 & 76 & 0 & 0 \\
S5 & 20 & 27 & 23 & 35 & 6 & 8 & 0 & 0 \\
Total & 4276 & 1969 & 5181 & 2407 & 2502 & 1557 & 6924 & 6186 \\
\hline Tunnel & $\mathbf{5 a}$ & $\mathbf{5 a}$ & $\mathbf{5 b}$ & $\mathbf{5 b}$ & $\mathbf{6 a}$ & $\mathbf{6 a}$ & - & - \\
\hline S1 & 3857 & 992 & 296 & 0 & 4604 & 2942 & - & - \\
S2 & 3282 & 3868 & 1416 & 0 & 919 & 1485 & - & - \\
S3 & 226 & 677 & 302 & 1056 & 426 & 604 & - & - \\
S4 & 0 & 0 & 178 & 104 & 0 & 37 & - & - \\
S5 & 0 & 0 & 50 & 67 & 21 & 16 & - & - \\
Total & 7364 & 5536 & 2241 & 1226 & 5970 & 5083 & - & - \\
\hline & & & & & & & - & - \\
\end{tabular}


Table 12. Total energy consumption, annual $\mathrm{CO}_{2}$ emission (using the emission factor 1058.95 $\mathrm{kgCO}_{2} / \mathrm{MWh}$ e) per electricity mix of Greece $\left.[73,74]\right)$ and energy savings comparisons between the examined scenarios for the period from 5 February, 2020 to 13 February, 2020.

\begin{tabular}{|c|c|c|c|c|c|c|}
\hline \multirow{2}{*}{ Scenario } & \multirow{2}{*}{ Description } & \multirow{2}{*}{$\begin{array}{c}\text { Energy } \\
\text { Consumption } \\
(\mathrm{kWh})\end{array}$} & \multirow{2}{*}{$\begin{array}{c}\mathrm{CO}_{2} \\
\text { Emission (tn) }\end{array}$} & \multicolumn{3}{|c|}{ Energy Savings (\%) } \\
\hline & & & & $\begin{array}{l}\text { Due to } \\
\text { New Lth' }\end{array}$ & $\begin{array}{l}\text { Due to LED } \\
\text { Luminaires }\end{array}$ & Total \\
\hline A & $\begin{array}{l}\text { Switching control with } \\
\text { existing Lth }\end{array}$ & 59,507 & 63.0 & - & - & - \\
\hline B & $\begin{array}{l}\text { Switching control with } \\
\text { newly calculated Lth' }\end{array}$ & 40,784 & 43.2 & $31.5 \%$ & - & $31.5 \%$ \\
\hline $\mathrm{C} 1$ & $\begin{array}{l}\text { LED Retrofit } 10 \% \text { step } \\
\text { control dimming (Lth) }\end{array}$ & 23,792 & 25.2 & - & $56.9 \%$ & $56.9 \%$ \\
\hline D1 & $\begin{array}{l}\text { LED Retrofit continuous } \\
\text { dimming (Lth) }\end{array}$ & 22,659 & 24.0 & - & $61.9 \%$ & $61.9 \%$ \\
\hline $\mathrm{C} 2$ & $\begin{array}{l}\text { LED Retrofit 10\% step } \\
\text { control dimming (Lth') }\end{array}$ & 9483 & 10.0 & $22.9 \%$ & $56.9 \%$ & $79.8 \%$ \\
\hline D2 & $\begin{array}{l}\text { LED Retrofit continuous } \\
\text { dimming (Lth') }\end{array}$ & 9032 & 9.6 & $22.9 \%$ & $61.9 \%$ & $84.8 \%$ \\
\hline
\end{tabular}

\section{Discussion and Conclusions}

The total annual electrical and primary energy consumptions of the existing installation (11 tunnels) were $2715 \mathrm{MWh}$ and $7874 \mathrm{MWh}$ correspondingly (Figure 7). The energy consumption from the examined period (Table 12) was normalized for a year, while the Primary Energy Numeric Indicator (kWh $p=2.9$ $\times \mathrm{kWh}$ e [75]) from Greece was used in order to convert the electrical to primary energy.

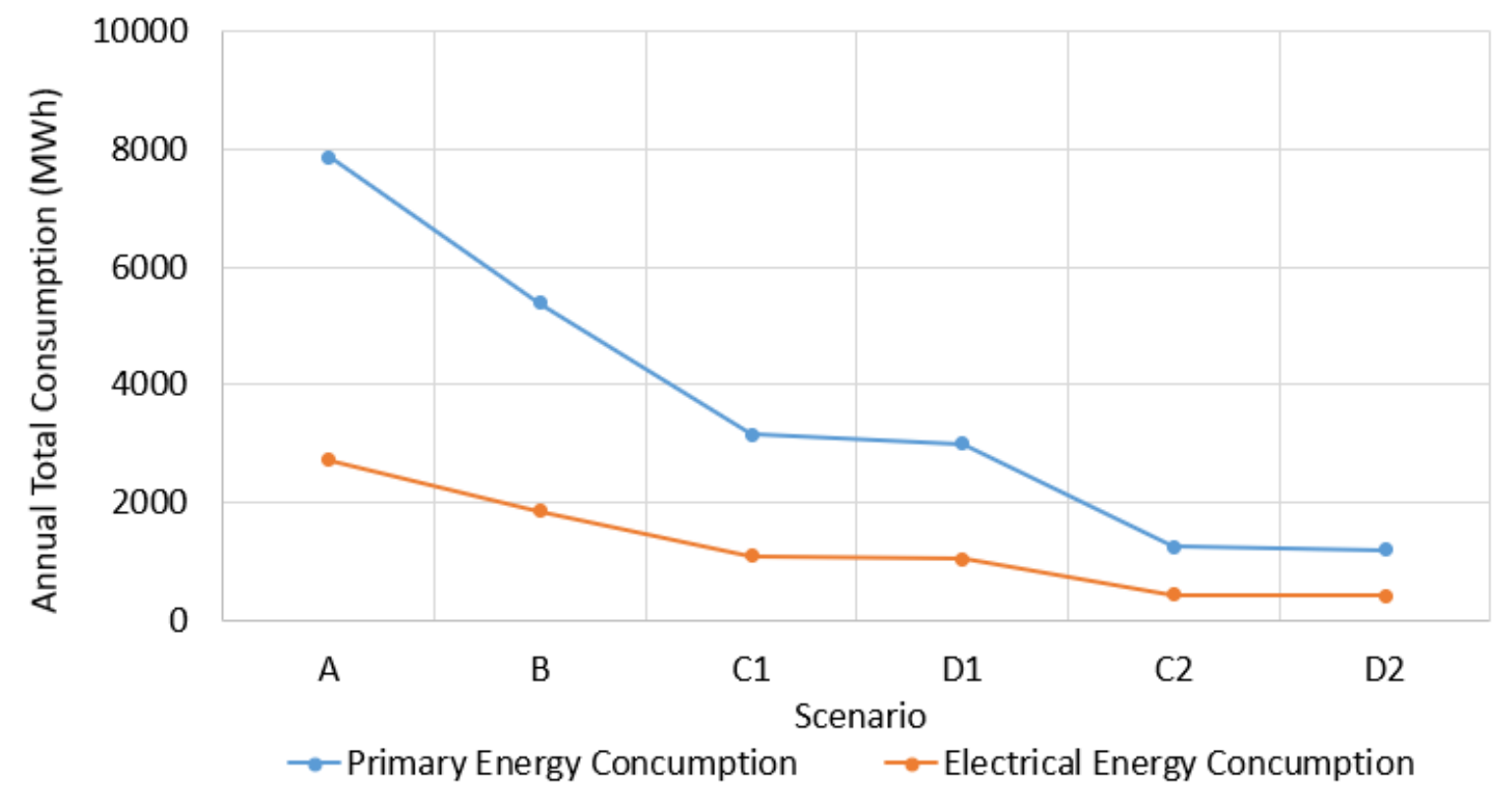

Figure 7. Total annual electrical and primary energy consumption for the examined scenarios.

Using the proposed methodology, the primary energy consumption can be reduced to $5396 \mathrm{MWh}$ (Figure 7) while the corresponding annual $\mathrm{CO}_{2}$ emission reduction is $904.6 \mathrm{tn}$. Thus, the energy savings can reach a figure of $31 \%$ using the new switching control strategy, according to the calculated Lth'. If combined with the retrofitting of existing luminaires with LED technology, the energy savings can increase and reach $62 \%$. The corresponding difference in energy savings between Scenario B and C2 $(31 \%)$ could not be viable as the cost of a LED tunnel luminaire, including the labor work for the new installation, is still high. However, using the new Lth' values (Scenario D, Figure 8) energy savings are $23 \%$, while by retrofitting the existing luminaires with LEDs, additional energy savings of up to $62 \%$ can be achieved. Figure 9 presents the annual energy costs together with the initial costs of the LED 
luminaires versus the annual primary energy consumption per square meter of the entrance zone of the examined tunnels. Each dot represents a case examined while the cases are grouped (different color) according to the scenarios. A price of 1200 euros per luminaire was taken as the initial cost of the LED luminaire, the cost of energy was calculated at 0.15 euros per $\mathrm{kWh}$ while the Primary Energy Factor was considered equal to 2.9 (Greece, [75]). The lower primary energy consumption and the cost are, (lower left part of the diagram in Figure 9) the more the beneficial is the action of the examined scenario. It seems that Scenario B (orange dots), represents the most beneficial one.

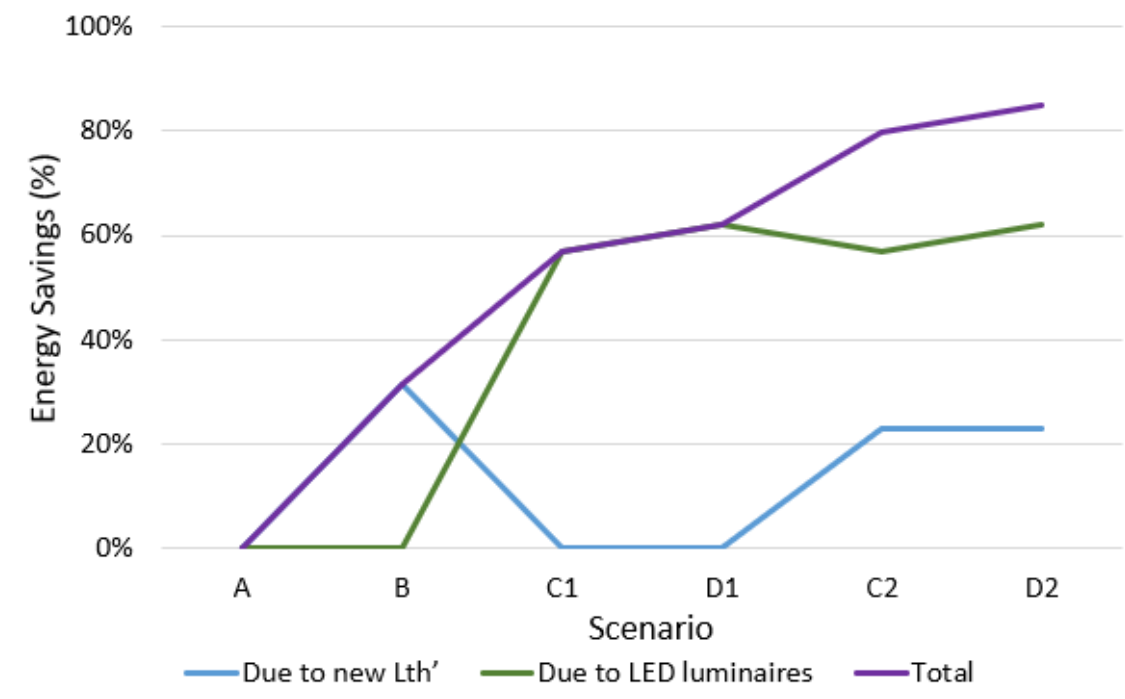

Figure 8. Breakdown of the energy savings due to the new calculated Lth' values and the retrofit of the existing luminaires with new LED luminaires for each of the examined scenarios.

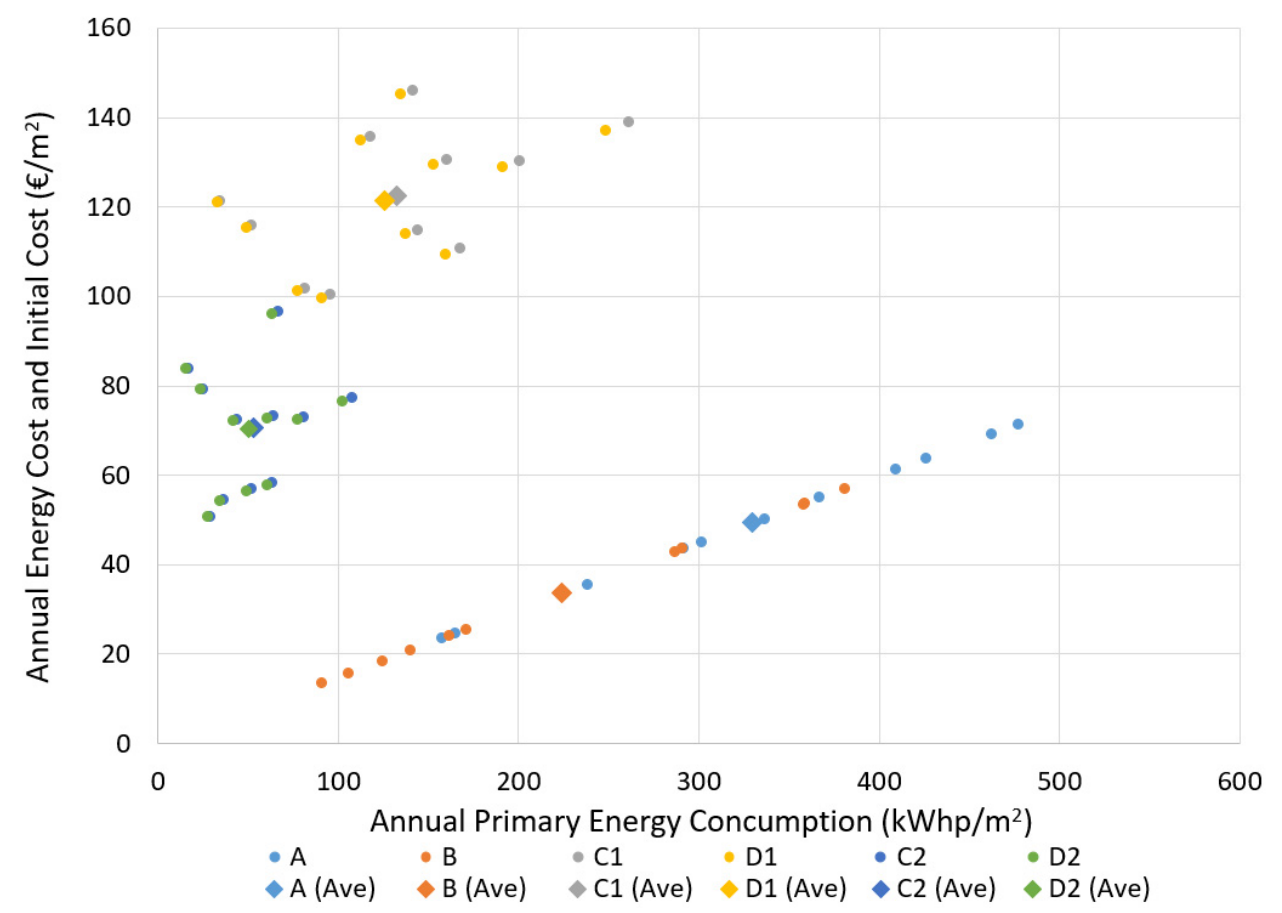

Figure 9. Annual energy cost and initial cost for LED luminaires versus the annual primary energy consumption per square meter of the entrance zone of the examined tunnels (11 tunnels in regards 6 scenarios with the corresponding average values per scenario). 
From the aforementioned results, it is evident that over-illumination and oldness of the existing tunnels result in increased and unwanted energy consumption especially in the daytime. A technical committee from the International Commission of Illumination (CIE 4-53 Tunnel Lighting Evolution) for tunnel upgrading has been formed [76] in an effort to minimize energy consumption. In addition, many lighting experts propose various actions such as using daylight control systems and different types of pavement in a similar attempt to reduce energy consumption. The proposed methodology, although simple, is not fully integrated into current energy saving policies. The revision of the Lth values should be a step taken prior to the action of replacing the existing lighting system with LED luminaires. The paper proposes a switching control strategy, which can be a useful tool for lighting designers, road authorities, and lighting experts. This switching control combined with the traffic weighted L20 method as described in CR14380 (Scenario B), can result in significant energy savings at no extra cost. Calculations were performed and energy savings was, on average, $31 \%$ varying from $11 \%$ to $54 \%$ depending on the tunnel. By replacing existing luminaires with LEDs with the existing threshold luminance Lth (Scenarios C1 and C2), energy savings can reach $62 \%$ while with the new threshold luminance Lth' (Scenarios D1 and D2), the corresponding values can reach a figure of $85 \%$. Even with the replacement of the existing lighting systems with LEDs, the effect of determining the new threshold luminance Lth' can result in $23 \%$ more energy savings (comparing C and D scenarios). Thus, the proposed methodology is suitable for being considered in retrofit actions with LED luminaires. However, this increase in energy savings is accompanied by the additional cost of the 2018 new LED luminaires (scenario C) or of the 1227 luminaires for scenario D, together with a new Supervisory Control and Data Acquisition system, as well as extra installation costs, such as wiring and the corresponding labor cost. In many cases, the extra cost for a new lighting installation compared with the no-cost switching strategy could make the renewal of the installation unsustainable if the cost of the luminaires is high. In addition, the proposed methodology a) is easy to apply with immediate results, $b$ ) the calculation of the new L20 values could be necessary in order to evaluate the initial design due to safety reasons, and c) no tender is required for its realization.

For future research, the proposed method could also be combined with traffic detection sensors, as the traffic volume can determine the tunnel class and thus the necessary lighting needs. For example, a tunnel class 3 with high traffic flow, could result in class 2 with medium traffic flow for a time period. As factor $\mathrm{k}$ will be defined by lower values, the new Lth' values should determine a new control switching. In general, the energy savings using traffic intensity detector parameters could end up to $50 \%$ [77-83]. Furthermore, frequent luminance measurements could enhance the energy savings. Monitoring the real situation of the lighting system, the switching system of SCADA can be fine-tuned, taking into account the lumen maintenance control strategy technique and the actual lighting levels. For this procedure, there are several novel methods for road luminance measurements, where luminance measurements are combined into mobile mapping systems and three-dimensional (3D) measuring [84-89].

Author Contributions: Conceptualization, L.T.D.; methodology, L.T.D.; software, L.T.D.; validation, L.T.D., I.S., and A.T.; data curation, L.T.D., I.S., and K.F.; writing-original draft preparation, L.T.D.; writing-review and editing, L.T.D., I.S., A.T., L.C., and K.F.; visualization, L.T.D. and L.C.; supervision, L.T.D., I.S., and K.F.; project administration, L.T.D. and K.F. All authors have read and agreed to the published version of the manuscript.

Funding: This research received no external funding.

Acknowledgments: This case study was part of the project "Examination of the upgrade of the lighting system with LED luminaires in National Highway Road PATHE Athens-Lamia". The final result and the economic criteria were kept anonymous for commercial reasons. The Company, by signing the Concession Agreement dated 19-12-2006 with the Greek State, which has been ratified by Law 3555/2007 and amended by the Concession Agreement Amendment Agreement dated 29-11-2013 (Law 4219/2013) and is currently in force, undertook the implementation of the Project "Design - Construction - Financing - Operation - Maintenance and Exploitation of Ionia Odos Motorway from Antirrio to Ioannina, PATHE motorway Athens (Metamorphossi i/c) - Maliakos (Skarfia) and PATHE connecting branch (Schimatari-Chalkida)".

Conflicts of Interest: The authors declare no conflict of interest. 


\section{Nomenclature}

Factor k

Lth

Lth (S1)

$\mathrm{Lth}^{\prime}\left(\mathrm{S}_{\mathrm{N}}\right)$

L20

L20 formula: Lc

L20 formula: $\mathrm{L}_{\mathrm{R}}$

L20 formula: $\mathrm{L}_{\mathrm{E}}$

L20 formula: $\gamma$

L20 formula: $\rho$

L20 formula: $\varepsilon$

Over Lit Triggering

Percentage (OLTP)
Threshold zone luminance ratio $(\mathrm{k})$ at a point: the ratio between the threshold zone luminance Lth and the access zone luminance L20. Typical values are given by [31] Threshold zone luminance, the average road surface luminance of a transverse strip at a given location in the threshold zone of the tunnel (as a function of the measurement grid). Lth (SN) is the Lth of the initial design of the existing tunnel for SN light stage, $\mathrm{S}_{\mathrm{N}}$ is the corresponding lighting stage (S1, S2, etc.)

Lth' (S1) is the luminance requirement for the new threshold zone for S1 stage

Average luminance contained in a conical field of view, subtending an angle of $20^{\circ}$ with the apex at the position of the eye of an approaching driver and aimed at the left of the tunnel mouth. L20 is assessed from a point at a distance equal to the stopping distance from the tunnel portal at the middle of the relevant carriage-way or traffic lane.

Typical values of sky luminance depending the driving direction given by [31]

Typical values of road luminance depending the driving direction given by [31]

Typical values of surrounding luminance depending the driving direction given by [31]

Percentage of the area of the sky covering the area contributing to the L20 value at the tunnel entrance

Percentage of the area of the road covering the area contributing to the L20 value at the tunnel entrance

Percentage of the area of the surrounding covering the area contributing to the L20 value at the tunnel entrance

Lth (SN)/Lth' (S1) Where Lth (SN) is the Lth of the initial design of the existing tunnel for SN light stage, Lth' (S1) is the luminance requirement for the new threshold zone for S1 stage and $\mathrm{SN}$ is the corresponding lighting stage ( $\mathrm{S} 1$ for $\mathrm{N}=1, \mathrm{~S} 2$ for $\mathrm{N}=2$, etc.). Thereafter OLTPR $_{\mathrm{SN}}$ represents (in percentage) the new triggering of each of the existing lighting circuit for SN light stage. This percentage is necessary for the specification of the new triggering of the existed lighting circuits based on the new lower lighting requirements. It is evident that the proposed triggering will now depend on the Lth' and since the existing lighting achieves specific lighting levels due to the existing lighting circuits, their triggering has to be redefined.

\section{References}

1. Zissis, G. Energy consumption and environmental and economic impact of lighting: The current situation. In Handbook of Advanced Lighting Technology; Karlicek, R., Sun, C.C., Zissis, G., Ma, R., Eds.; Springer: Cham, Switzerland, 2016; pp. 1-13. [CrossRef]

2. Traverso, M.; Donatello, S.; Moons, H.; Rodriguez Quintero, R.; Gama Caldas, M.; Wolf, O. Revision of the EU Green Public Procurement Criteria for Road Lighting and Traffic Signals; EUR 29631 EN; Publications Office of the European Union: Luxembourg, 2019; JRC115406; ISBN 978-92-79-99077-9. [CrossRef]

3. Ntanos, S.; Kyriakopoulos, G.; Skordoulis, M.; Chalikias, M.; Arabatzis, G. An application of the new environmental paradigm (NEP) scale in a Greek context. Energies 2019, 12, 239. [CrossRef]

4. Arabatzis, G.; Kyriakopoulos, G.; Tsialis, P. Typology of regional units based on RES plants: The case of Greece. Renew. Sustain. Energy Rev. 2017, 78, 1424-1434. [CrossRef]

5. Kolovos, K.G.; Kyriakopoulos, G.; Chalikias, M.S. Co-evaluation of basic wood fuel types used as alternative heating sources to existing energy network. J. Environ. Prot. Ecol. 2011, 12, 733-742.

6. Grigoropoulos, C.; Doulos, L.; Zerefos, S.; Tsangrassoulis, A.; Bhusal, P. Estimating the benefits of increasing the recycling rate of lamps from the domestic sector: Methodology, opportunities and case study. Waste Manag. 2020, 101, 188-199. [CrossRef] [PubMed]

7. Mehri, A.; Sajedifar, J.; Abbasi, M.; Naimabadi, A.; Mohammadi, A.A.; Teimori, G.H.; Zakerian, S.A. Safety evaluation of lighting at very long tunnels on the basis of visual adaptation. Saf. Sci. 2019, 116, 196-207. [CrossRef]

8. Han, X.; Shao, Y.; Yang, S.; Yu, P. Entropy-Based Effect Evaluation of Delineators in Tunnels on Drivers' Gaze Behavior. Entropy 2020, 22, 113. [CrossRef]

9. Peña-García, A.; Hurtado, A.; Aguilar-Luzón, M.C. Impact of public lighting on pedestrians' perception of safety and well-being. Saf. Sci. 2015, 78, 142-148. [CrossRef]

10. Gilandeh, S.S.; Hosseinlou, M.H.; Anarkooli, A.J. Examining bus driver behavior as a function of roadway features under daytime and nighttime lighting conditions: Driving simulator study. Saf. Sci. 2018, 110, 142-151. [CrossRef] 
11. Ye, Z.T.; Chen, C.L.; Chen, L.-C.; Tien, C.H.; Nguyen, H.T.; Wang, H.-C. Hollow Light Guide Module Involving Mini Light-Emitting Diodes for Asymmetric Luminous Planar Illuminators. Energies 2019, $12,2755$. [CrossRef]

12. Djuretic, A.; Kostic, M. Actual energy savings when replacing high-pressure sodium with LED luminaires in street lighting. Energy 2018, 157, 367-378. [CrossRef]

13. Djuretic, A.; Skerovic, V.; Arsic, N.; Kostic, M. Luminous flux to input power ratio, power factor and harmonics when dimming high-pressure sodium and LED luminaires used in road lighting. Lighting Res. Technol. 2019, 51, 304-323. [CrossRef]

14. Anthopoulou, E.; Doulos, L. The effect of the continuous energy efficient upgrading of LED street lighting technology: The case study of Egnatia Odos. In Proceedings of the 2019 Second Balkan Junior Conference on Lighting (Balkan Light Junior), Plovdiv, Bulgaria, 19-21 September 2019. Category number CFP19BLJ-ART; Code 153526. [CrossRef]

15. Moretti, L.; Cantisani, G.; Carrarini, L.; Bezzi, F.; Cherubini, V.; Nicotra, S. Italian Road Tunnels: Economic and Environmental Effects of an On-Going Project to Reduce Lighting Consumption. Sustainability 2019, 11, 4631. [CrossRef]

16. Jettanasen, C.; Ngaopitakkul, A. Characteristics and Effects of Conducted Emission from Grid-Connected and Stand-Alone Micro-Inverters in a Nano-Grid Road Lighting System. Sustainability 2019, 11, 5690. [CrossRef]

17. Hermoso-Orzáez, M.J.; Lozano-Miralles, J.A.; Lopez-Garcia, R.; Brito, P. Environmental Criteria for Assessing the Competitiveness of Public Tenders with the Replacement of Large-Scale LEDs in the Outdoor Lighting of Cities as a Key Element for Sustainable Development: Case Study Applied with PROMETHEE Methodology. Sustainability 2019, 11, 5982. [CrossRef]

18. Ogando-Martínez, A.; Troncoso-Pastoriza, F.; Eguía-Oller, P.; Granada-Álvarez, E.; Erkoreka, A. Model Calibration Methodology to Assess the Actual Lighting Conditions of a Road Infrastructure. Infrastructures 2020, 5, 2. [CrossRef]

19. Pracki, P.; Skarżyński, K. A Multi-Criteria Assessment Procedure for Outdoor Lighting at the Design Stage. Sustainability 2020, 12, 1330. [CrossRef]

20. Doulos, L.T.; Sioutis, I.; Kontaxis, P.A.; Zissis, G.; Faidas, K. A decision support system for assessment of street lighting tenders based on energy performance indicators and environmental criteria: Overview, methodology and case study. Sustain. Cities Soc. 2019, 51, 101759. [CrossRef]

21. Peña-García, A.; Sęziwy, A. Optimizing Lighting of Rural Roads and Protected Areas with White Light: A Compromise among Light Pollution, Energy Savings, and Visibility. LEUKOS 2019, 16, 147-156. [CrossRef]

22. Ardavani, O.; Zerefos, S.; Doulos, L.T. Redesigning the exterior lighting as part of the urban landscape: The role of transgenic bioluminescent plants in Mediterranean urban and suburban lighting environments. J. Clean. Prod. 2020, 242, 118477. [CrossRef]

23. Bará, S.; Lima, R.C.; Zamorano, J. Monitoring Long-Term Trends in the Anthropogenic Night Sky Brightness. Sustainability 2019, 11, 3070. [CrossRef]

24. Galatanu, C.D.; Husch, M.; Canale, L.; Lucache, D. Targeting the Light Pollution: A Study Case. In Proceedings of the IEEE International Conference on Environment and Electrical Engineering and 2019 IEEE Industrial and Commercial Power Systems Europe, EEEIC/I and CPS Europe, Genoa, Italy, 11-14 June 2019. Article number 8783515.

25. Kyba, C.C.M.; Wagner, J.M.; Kuechly, H.U.; Walker, C.E.; Elvidge, C.D.; Falchi, F.; Ruhtz, T.; Fischer, J.; Hölker, F. Citizen Science Provides Valuable Data for Monitoring Global Night Sky Luminance. Sci. Rep. 2013, 3, 1835. [CrossRef] [PubMed]

26. Papalambrou, A.; Doulos, L.T. Identifying, Examining, and Planning Areas Protected from Light Pollution. The Case Study of Planning the First National Dark Sky Park in Greece. Sustainability 2019, 11, 5963. [CrossRef]

27. Zielinska-Dabkowska, K.M.; Hartmann, J.; Sigillo, C. LED Light Sources and Their Complex Set-Up for Visually and Biologically Effective Illumination for Ornamental Indoor Plants. Sustainability 2019, 11, 2642. [CrossRef]

28. Zielinska-Dabkowska, K.M.; Xavia, K. Global Approaches to Reduce Light Pollution from Media Architecture and Non-Static, Self-Luminous LED Displays for Mixed-Use Urban Developments. Sustainability 2019, 11, 3446. [CrossRef] 
29. International Commission on Illumination. Guide on the Limitation of the Effects of Obtrusive Light from Outdoor Lighting Installations, 2nd ed.; Technical Report CIE 150; International Commission on Illumination: Vienna, Austria, 2017; ISBN 978-3-902842-48-0.

30. Schulte-Römer, N.; Meier, J.; Dannemann, E.; Söding, M. Lighting Professionals versus Light Pollution Experts? Investigating Views on an Emerging Environmental Concern. Sustainability 2019, 11, 1696. [CrossRef]

31. European Committee for Standardization. European Norm CR 14380 Lighting Applications_Tunnel Lighting; European Committee for Standardization: Brussels, Belgium, 2003.

32. International Commission on Illumination. Guide for the Lighting of Road Tunnels and Underpasses; Technical Report CIE 88; International Commission on Illumination: Vienna, Austria, 2004; ISBN 3 901906312.

33. Mavridou, T.; Doulos, L.T. Evaluation of Different Roof Types Concerning Daylight in Industrial Buildings during the Initial Design Phase: Methodology and Case Study. Buildings 2019, 9, 170. [CrossRef]

34. Mantzourani, K.; Doulos, L.; Kontadakis, A.; Tsangrassoulis, A. The effect of the daylight zone on lighting energy savings. IOP Conf. Ser. Earth Environ. Sci. 2020, 410, 012099. [CrossRef]

35. Kontadakis, A.; Doulos, L.; Mantzourani, A.; Tsangrassoulis, A. Performance assessment of an active sunlight redirection system in areas with different climate: A comparison. IOP Conf. Ser. Earth Environ. Sci. 2020, 410, 012098. [CrossRef]

36. Moretti, L.; Cantisani, G.; di Mascio, P. Management of road tunnels: Construction, maintenance and lighting costs. Tunn. Undergr. Space Technol. 2016, 51, 84-89. [CrossRef]

37. Moretti, L.; Cantisani, G.; di Mascio, P.; Caro, S. Technical and economic evaluation of lighting and pavement in Italian road tunnels. Tunn. Undergr. Space Technol. 2017, 65, 42-52. [CrossRef]

38. López, J.C.; Grindlay, A.L.; Peña-García, A. A proposal for evaluation of energy consumption and sustainability of road tunnels: The sustainability vector. Tunn. Undergr. Space Technol. 2017, 65, 53-61. [CrossRef]

39. Peña-García, A.; Escribano, R.; Gil-Martín, L.M.; Espín-Estrella, A. Computational optimization of semi-transparent tension structures for the use of solar light in road tunnels. Tunn. Undergr. Space Technol. 2012, 32, 127-131. [CrossRef]

40. Pena-Garcia, A.; Lopez, J.C.; Grindlay, A.L. Decrease of energy demands of lighting installations in road tunnels based in the forestation of portal surroundings with climbing plants. Tunn. Undergr. Space Technol. 2015, 46, 111-115. [CrossRef]

41. García-Trenasa, T.; Lópeza, J.C.; Peña-García, A. Proposal to forest Alpine tunnels surroundings to enhance energy savings from the lighting installations. Towards a standard procedure. Tunn. Undergr. Space Technol. 2018, 78, 1-7. [CrossRef]

42. Onaygil, S.; Guler, O.; Erkin, E. Determination of the effects of structural properties on tunnel lighting with examples from Turkey. Tunn. Undergr. Space Technol. 2003, 18, 85-91. [CrossRef]

43. Cantisani, G.; D'Andrea, A.; Moretti, L. Natural lighting of road pre-tunnels: A methodology to assess the luminance on the pavement-Part I. Tunnelling and Underground Space Technology 2018, 73, 37-47. [CrossRef]

44. Drakou, D.; Burattini, C.; Bisegna, F.; Gugliermetti, F. Study of a daylight "filter" zone in tunnels. In Proceedings of the IEEE 15th International Conference on Environment and Electrical Engineering (EEEIC), Rome, Italy, 10-13 June 2015; pp. 649-652.

45. Drakou, D.; Celucci, L.; Burattini, C.; Nardecchia, F.; Gugliermetti, F. Study for optimizing the daylight "filter" in a pre-tunnel structure. In Proceedings of the IEEE 16th International Conference on Environment and Electrical Engineering (EEEIC), Florence, Italy, 7-10 June 2016; p. 4.

46. Kontadakis, A.; Tsangrassoulis, A.; Doulos, L.; Zerefos, S. A Review of Light Shelf Designs for Daylit Environments. Sustainability 2018, 10, 71. [CrossRef]

47. Tsangrassoulis, A.; Doulos, L.; Santamouris, M.; Fontoynont, M.; Maamari, F.; Wilson, M.; Jacobs, A.; Solomon, J.; Zimmerman, A.; Pohl, W.; et al. On the energy efficiency of a prototype hybrid daylighting system. Sol. Energy 2005, 79, 56-64. [CrossRef]

48. Gil-Martín, L.; Peña-García, A.; Jiménez, A.; Hernández-Montes, E. Hernández-Montes. Study of light-pipes for the use of sunlight in road tunnels: From a scale model to real tunnels. Tunn. Undergr. Space Technol. 2014, 41, 82-87. [CrossRef] 
49. Peña-García, A.; Gil-Martín, L.; Hernández-Montes, E. Use of sunlight in road tunnels: An approach to the improvement of light-pipes' efficacy through heliostats. Tunn. Undergr. Space Technol. 2016, 60, 135-140. [CrossRef]

50. Gil-Martín, L.; Peña-García, A.; Hernández-Montes, E.; Espín-Estrella, A. Tension structures: A way towards sustainable lighting in road tunnels. Tunn. Undergr. Space Technol. 2011, 26, 223-227. [CrossRef]

51. Peña-García, A.; Gómez-Lorente, D. Installation of solar panels in the surroundings of tunnel portals: A double-targeted strategy to decrease lighting requirements and consumption. Tunn. Undergr. Space Technol. 2020, 97, 103251. [CrossRef]

52. Peña-García, A.; Gil-Martín, L. Study of pergolas for energy savings in road tunnels. Comparison with tension structures. Tunn. Undergr. Space Technol. 2013, 35, 172-177. [CrossRef]

53. Gil-Martín, L.; Gómez-Guzmán, A.; Peña-García, A. Use of diffusers materials to improve the homogeneity of sunlight under pergolas installed in road tunnels portals for energy savings. Tunn. Undergr. Space Technol. 2015, 48, 123-128. [CrossRef]

54. Salam, A.O.A.; Mezher, K. Energy saving in tunnels lighting using shading structures. In Proceedings of the 2014 International Renewable and Sustainable Energy Conference (IRSEC), Ouarzazate, Morocco, 17-19 October 2014; pp. 519-524, IRSEC 20147059842.

55. Peña-García, A. The impact of lighting on drivers well-being and safety in very long underground roads: New challenges for new infrastructures. Tunn. Undergr. Space Technol. 2018, 80, 38-43. [CrossRef]

56. Galatanu, C.D.; Canale, L.; Zissis, G.; Gherasim, I. Measuring the Driver Exposure to the Light Pollution Developing Experimental Setup. In Proceedings of the 2018 IEEE International Conference on Environment and Electrical Engineering and 2018 IEEE Industrial and Commercial Power Systems Europe (EEEIC/I\&CPS Europe), Palermo, Italy, 12-15 June 2018; pp. 1-6. [CrossRef]

57. Galatanu, C.D.; Canale, L.; Lucache, D.D.; Zissis, G. Reduction in Light Pollution by Measurements According to EN 13201 Standard. In Proceedings of the 2018 International Conference and Exposition on Electrical and Power Engineering (EPE), Iasi, Romania, 18-19 October 2018; pp. 1074-1079. [CrossRef]

58. Lopez, J.; Peña-García, A. Determination of lighting and energy demands of road tunnels using vehicle based photographs of the portal gates: An accessible and safe tool for tunnel renewal and maintenance. Tunn. Undergr. Space Technol. 2018, 78, 8-15. [CrossRef]

59. Li, S. An optimal model for tunnel lighting control systems. Tunn. Undergr. Space Technol. 2015, 49, 328-335. [CrossRef]

60. Doulos, L.; Tsangrassoulis, A.; Kontaxis, P.; Kontadakis, A.; Topalis, F. Harvesting daylight with LED or T5 fluorescent lamps? The role of dimming. Energy Build. 2017, 140, 336-347. [CrossRef]

61. Doulos, L.; Tsangrassoulis, A.; Topalis, F. Quantifying energy savings in daylight responsive systems: The role of dimming electronic ballasts. Energy Build. 2008, 40, 36-50. [CrossRef]

62. Adam, G.; Kontaxis, P.; Doulos, L.; Madias, E.-N.; Bouroussis, C.; Topalis, F.V. Embedded microcontroller with a CCD camera as a digital lighting control system. Electronics 2019, 8, 33. [CrossRef]

63. Doulos, L.; Tsangrassoulis, A.; Topalis, F. Multi-criteria decision analysis to select the optimum position and proper field of view of a photosensor. Energy Convers. Manag. 2014, 86, 1069-1077. [CrossRef]

64. Topalis, F.V.; Doulos, L.T. Ambient Light Sensor Integration (Book Chapter). In Handbook of Advanced Lighting Technology; Sun, C.C., Zissis, G., Ma, R., Eds.; Springer: Cham, Switzerland, 2017; pp. 607-634. [CrossRef]

65. Madias, E.-N.; Doulos, L.; Kontaxis, P.; Topalis, F. A decision support system for techno-economic evaluation of indoor lighting systems with LED luminaires. Oper. Res. 2019, 1-20. [CrossRef]

66. Manolis, E.; Doulos, L.T.; Niavis, S.; Canale, L. The impact of energy efficiency indicators on the office lighting planning and its implications for office lighting market. In Proceedings of the 2019 IEEE International Conference on Environment and Electrical Engineering and 2019 IEEE Industrial and Commercial Power Systems Europe (EEEIC/I\&CPS Europe), Genova, Italy, 11-14 June 2019; pp. 1-6. [CrossRef]

67. Doulos, L.; Kontadakis, A.; Madias, E.; Sinou, M.; Tsangrassoulis, A. Minimizing energy consumption for artificial lighting in a typical classroom of a Hellenic public school aiming for near Zero Energy Building using LED DC luminaires and daylight harvesting systems. Energy Build. 2019, 194, 201-217. [CrossRef]

68. Pachamanov, A.; Pachamanova, D. Optimization of the light distribution of luminaries for tunnel and street lighting. Eng. Optim. 2008, 40, 47-65. [CrossRef] 
69. Salata, F.; Golasi, I.; Bovenzi, S.; de Lieto Vollaro, E.; Pagliaro, F.; Cellucci, L.; Coppi, M.; Gugliermetti, F.; de Lieto Vollaro, A. Energy Optimization of Road Tunnel Lighting Systems. Sustainability 2015, 7, 9664-9680. [CrossRef]

70. Salata, F.; Golasi, I.; Poliziani, A.; Futia, A.; de Lieto Vollaro, E.; Coppi, M.; de Lieto Vollaro, A. Management Optimization of the Luminous Flux Regulation of a Lighting System in Road Tunnels. A First Approach to the Exertion of Predictive Control Systems. Sustainability 2016, 8, 1092. [CrossRef]

71. Doulos, L.T.; Sioutis, I.; Tsangrassoulis, A.; Canale, L.; Faidas, K. Minimizing lighting consumption in existing tunnels using a no-cost fine-tuning method for switching lighting stages according revised luminance levels. In Proceedings of the 2019 IEEE International Conference on Environment and Electrical Engineering and 2019 IEEE Industrial and Commercial Power Systems Europe (EEEIC/I\&CPS Europe), Genova, Italy, 11-14 June 2019; pp. 1-6. [CrossRef]

72. RELUX Tunnel Lighting Simulation Tool. Available online: https://reluxnet.relux.com/en/ (accessed on 28 February 2020).

73. Rigamonti, L.; Grosso, M.; Giugliano, M. Life cycle assessment for optimising the level of separated collection in integrated MSW management systems. Waste Manag. 2009, 29, 934-944. [CrossRef]

74. Kourkoumpas, D.-S.; Karellas, S.; Kouloumoundras, S.; Koufodimos, G.; Grammelis, P.; Kakaras, E. Comparison of Waste-to-Energy Processes by Means of Life Cycle Analysis Principles regarding the Global Warming Potential Impact: Applied Case Studies in Greece, France and Germany. Waste Biomass Valorization 2015, 6, 605-621. [CrossRef]

75. Greek Energy Efficiency Regulation of Buildings; Journal of the Government of the Hellenic Republic ( $\triangle \mathrm{E}$ ПЕА/окк.178581): Athens, Greece, 2017.

76. International Commission on Illumination. Technical Committee 4-53 (2020). Tunnel Lighting Evolution. Available online: http://www.cie.co.at/technicalcommittees/tunnel-lighting-evolution (accessed on 28 February 2020).

77. Wojnicki, I.; Kotulski, L. Empirical Study of How Traffic Intensity Detector Parameters Influence Dynamic Street Lighting Energy Consumption: A Case Study in Krakow, Poland. Sustainability 2018, 10, 1221. [CrossRef]

78. Wojnicki, I.; Ernst, S.; Kotulski, L. Economic Impact of Intelligent Dynamic Control in Urban Outdoor Lighting. Energies 2016, 9, 314. [CrossRef]

79. Shahzad, G.; Yang, H.; Ahmad, A.W.; Lee, C.; Gul, S.; Heekwon, Y.; Chankil, L. Energy-Efficient Intelligent Street Lighting System Using Traffic-Adaptive Control. IEEE Sens. J. 2016, 16, 5397-5405. [CrossRef]

80. Wojnicki, I.; Komnata, K.; Kotulski, L. Comparative Study of Road Lighting Efficiency in the Context of CEN/TR 132012004 and 2014 Lighting Standards and Dynamic Control. Energies 2019, 12, 1524. [CrossRef]

81. Sȩdziwy, A. Sustainable Street Lighting Design Supported by Hypergraph-Based Computational Model. Sustainability 2016, 8, 13. [CrossRef]

82. Lau, S.P.; Merrett, G.V.; Weddell, A.S.; White, N.M. A traffic-aware street lighting scheme for Smart Cities using autonomous networked sensors. Comput. Electr. Eng. 2015, 45, 192-207. [CrossRef]

83. Nellore, K.; Hancke, G.P. A Survey on Urban Traffic Management System Using Wireless Sensor Networks. Sensors 2016, 16, 157. [CrossRef] [PubMed]

84. Vaaja, M.; Kurkela, M.; Maksimainen, M.; Virtanen, J.; Kukko, A.; Lehtola, V.V.; Hyyppä, J.; Hyyppä, H. Mobile mapping of night-time road environment lighting conditions. Photogramm. J. Finl. 2018, 26, 1-17. [CrossRef]

85. Kurkela, M.; Maksimainen, M.; Vaaja, M.T.; Virtanen, J.; Kukko, A.; Hyyppä, J.; Hyyppä, H. Camera preparation and performance for 3D luminance mapping of road environments. Photogramm. J. Finl. 2017, 25, 1-23. [CrossRef]

86. Vaaja, M.T.; Kurkela, M.; Virtanen, J.-P.; Maksimainen, M.; Hyyppä, H.; Hyyppä, J.; Tetri, E. Luminance-Corrected 3D Point Clouds for Road and Street Environments. Remote Sens. 2015, 7, 11389-11402. [CrossRef]

87. Wojnicki, I.; Kotulski, L.; Sędziwy, A.; Ernst, S. Application of Distributed Graph Transformations to Automated Generation of Control Patterns for Intelligent Lighting Systems. J. Comput. Sci. 2017, 23, $20-30$. [CrossRef] 
88. Wojnicki, I.; Kotulski, L. Improving Control Efficiency of Dynamic Street Lighting by Utilizing the Dual Graph Grammar Concept. Energies 2018, 11, 402. [CrossRef]

89. Sęziwy, A.; Kotulski, L. Multi-agent System Supporting Automated GIS-based Photometric Computations. Procedia Comput. Sci. 2016, 80, 824-833. [CrossRef]

(C) 2020 by the authors. Licensee MDPI, Basel, Switzerland. This article is an open access article distributed under the terms and conditions of the Creative Commons Attribution (CC BY) license (http://creativecommons.org/licenses/by/4.0/). 